\title{
The Endophytic Microbiome as a Hotspot of Synergistic Interactions, with Prospects of Plant Growth Promotion
}

\author{
Udaya Kumar Vandana ${ }^{1, \dagger}{ }^{+}$Jina Rajkumari ${ }^{2,+}{ }^{+}$L. Paikhomba Singha ${ }^{2}$, Lakkakula Satish ${ }^{3,4}{ }^{\oplus}$, \\ Hemasundar Alavilli ${ }^{5}{ }^{\circ}$, Pamidimarri D.V.N. Sudheer ${ }^{6}$, Sushma Chauhan ${ }^{6}$, Rambabu Ratnala ${ }^{7}$, Vanisri Satturu ${ }^{8}$, \\ Pranab Behari Mazumder ${ }^{1}\left[\right.$ and Piyush Pandey ${ }^{2, *}$
}

1 Department of Biotechnology, Assam University Silchar, Assam 788011, India; uday21microbe@gmail.com (U.K.V.); pbmazumder65@gmail.com (P.B.M.)

2 Department of Microbiology, Assam University Silchar, Assam 788011, India; jinark91@gmail.com (J.R.); paikhom.as.in@gmail.com (L.P.S.)

3 Avram and Stella Goldstein-Goren Department of Biotechnology Engineering and the Ilse Katz Center for Meso and Nanoscale Science and Technology, Ben-Gurion University of the Negev, Beer Sheva 84105, Israel; satishlakkakula85@gmail.com

4 The Albert Katz International School for Desert Studies, The Jacob Blaustein Institutes for Desert Research, Ben-Gurion University of the Negev, Beer Sheva 84105, Israel

5 Department of Biochemistry and Molecular Biology, College of Medicine, Korea Molecular Medicine and Nutrition Research Institute, Korea University, Seoul 02841, Korea; alavilli.sundar@gmail.com

6 Amity Institute of Biotechnology, Amity University Chhattisgarh, Raipur 493225, India; pdvnsudheer@gmail.com (P.D.V.N.S.); sushma.chauhan163@gmail.com (S.C.)

7 TATA Institute for Genetics and Society, Bangalore 560065, India; rambabu.ratnala@gmail.com

check for updates

Citation: Vandana, U.K.; Rajkumari, J.; Singha, L.P.; Satish, L.; Alavilli, H.; Sudheer, P.D.V.N.; Chauhan, S.;

Ratnala, R.; Satturu, V.; Mazumder, P.B.; et al. The Endophytic Microbiome as a Hotspot of Synergistic Interactions, with Prospects of Plant Growth Promotion. Biology 2021, 10, 101.

https://doi.org/

10.3390/biology10020101

Received: 20 December 2020

Accepted: 29 January 2021

Published: 1 February 2021

Publisher's Note: MDPI stays neutral with regard to jurisdictional claims in published maps and institutional affiliations.

Copyright: (c) 2021 by the authors. Licensee MDPI, Basel, Switzerland. This article is an open access article distributed under the terms and conditions of the Creative Commons Attribution (CC BY) license (https:// creativecommons.org/licenses/by/ $4.0 /)$.
8 Institute of Biotechnology, Professor Jayashankar Telangana State Agricultural University, Rajendranagar, Hyderabad 500030, India; vanisreedhar1994@gmail.com

* Correspondence: piyushddn@gmail.com

+ These authors contribute equally to this work.

Simple Summary: Endophytic bacteria are plant-associated bacteria that live in the internal tissues of the plant without harming the host plant. They have an important role in plant growth promotion, as they directly or indirectly promote plant growth. They do it by inhibiting the growth of plant pathogens, and/or by producing various secondary metabolites. They are used in the agricultural sector as an eco-friendly alternative tool that helps to improve crop yield. Detection of plant defense response and identification of compounds synthesized by root endophytes are an effective means for their utilization in the agriculture sector as biofertilizers. Therefore, it is important to study the diversity of root endophytic microbial community, endophyte-host plant interactions and their colonization, and their activity for successful application in agricultural lands. Here, in this review, the potential of the root endophytic microbial community, colonization, and role in the improvement of plant growth has been explained. This could mark the potential use of endophytes for the benefit of plant growth and enhanced yield.

Abstract: The plant root is the primary site of interaction between plants and associated microorganisms and constitutes the main components of plant microbiomes that impact crop production. The endophytic bacteria in the root zone have an important role in plant growth promotion. Diverse microbial communities inhabit plant root tissues, and they directly or indirectly promote plant growth by inhibiting the growth of plant pathogens, producing various secondary metabolites. Mechanisms of plant growth promotion and response of root endophytic microorganisms for their survival and colonization in the host plants are the result of complex plant-microbe interactions. Endophytic microorganisms also assist the host to sustain different biotic and abiotic stresses. Better insights are emerging for the endophyte, such as host plant interactions due to advancements in 'omic' technologies, which facilitate the exploration of genes that are responsible for plant tissue colonization. Consequently, this is informative to envisage putative functions and metabolic processes crucial for endophytic adaptations. Detection of cell signaling molecules between host plants and identification of compounds synthesized by root endophytes are effective means for their utilization in the 
agriculture sector as biofertilizers. In addition, it is interesting that the endophytic microorganism colonization impacts the relative abundance of indigenous microbial communities and suppresses the deleterious microorganisms in plant tissues. Natural products released by endophytes act as biocontrol agents and inhibit pathogen growth. The symbiosis of endophytic bacteria and arbuscular mycorrhizal fungi (AMF) affects plant symbiotic signaling pathways and root colonization patterns and phytohormone synthesis. In this review, the potential of the root endophytic community, colonization, and role in the improvement of plant growth has been explained in the light of intricate plant-microbe interactions.

Keywords: root endophyte; rhizo-microbiome; rhizosphere; plant growth promotion; PGPR; plant-bacteria interaction

\section{Introduction}

The need for food security is becoming increasingly urgent, as it is anticipated that the worldwide population, which is currently at around 7 billion, will almost increase to 10 billion or more in the following 50 years [1]. The arable land for farming is turning to be a limited resource because of the urban turn of events and industrialization; henceforth, existing agricultural land should be used more efficiently, utilizing suitable agricultural practices [2]. The excessive use of synthetic fertilizer and other agrochemicals is increasing to achieve higher yield. However, this is not a sustainable strategy, because of the negative impacts it imposes on the environment. Soil health is affected through inappropriate fertilizer usage and also by continuous monoculture cropping and pesticide use (rhizosphere auto-toxicity) [3]. Besides, seepage of water from agrochemical-treated fields into water-bodies prompts eutrophication that affects the aquatic ecosystems [4].

Hence, researchers are focused on a wide range of opportunities to attain efficient agricultural land usage. The bacteria present in the rhizosphere cooperate with the host plant and offer positive effects on its growth [5]. Plant growth-promoting (PGP) elements are delivered by advantageous bacteria residing within or around the roots of plants, such as in the rhizosphere, known as the "plant growth-promoting rhizobacteria" (PGPR), which guard the plants against abiotic and biotic stressed environments, and also improve their physiological capacities [6]. These useful soil microbes, however plentiful in the rhizosphere, are generally under-exploited as bio-inoculants for upgrading crop production, particularly under abiotic stress [7]. Therefore, nowadays, PGPR are getting much attention among agricultural and environmental research as an eco-friendly tool for increasing crop yield, and also as a component of integrated plant nutrient management systems. Rhizobacteria present in the rhizosphere are found to be an efficient alternative for agrochemicals. The rhizosphere harbors a wide range of microbes, which directly interact with plant roots, and hence rhizosphere is considered a hotspot of bacterial diversity. Plant roots release several organic nutrients and plant effluents, such as sugars, amino acid, and send signals that stimulate microbial growth and production, which is why they nurture 5 to 10 times more fungi and 10 to 50 times more bacteria than ordinary soil [8]. Since root exudates contain the largest amount of carbon source within the soil, the rhizosphere houses a rich microbial community covering a large number of microbial taxa, associated to plant roots and termed as the rhizo-microbiome. Its composition is different from that of the microbial community of the surrounding soil. As a consequence, bacterial population compete for nutrients released in the rhizosphere [9]. Root branching order characterized by primary (stem-attached large), secondary (primary-attached medium), and fine (secondary-attached hair-like) roots have been reported to influence the abundance of microbial communities in the rhizosphere. Bacterial taxa belonging to Bradyrhizobium, Burkholderia, Pseudomonas, Sphingomonas, and Streptomyces were found to be abundant in the small root environment, which might be due to the mineral content and exposure with soil [10]. The composition of the rhizo-microbiome changes along with the plant 
maturation stages and plant genotype [11]. Microorganisms had been reported to promote plant growth within the rhizo-microbiome through direct or indirect mechanisms [12,13].

The plant-microbe interactions around roots are mostly mutualistic. These interactions help in the colonization at the root surface and support the development of plants [14]. Based on their metabolic activity and functional diversity, PGPR has a beneficial effect on the plant's growth. They help in plant growth promotion by forming symbiotic associations, nitrogen fixation, phosphate solubilization, and production of essential phytohormone such as indole acetic acid (IAA), abscisic acid, cytokinin, etc. However, they also help plants indirectly through resistance/tolerance to biotic stresses and abiotic stress. This is because they exert biocontrol and have an antagonistic effect by various means, such as by the production of antibiotic, lipopeptide, cell wall degrading enzyme, volatile compound, $\mathrm{HCN}$, and siderophore. They reduce abiotic stresses in plants, as they have a role in increasing tolerance against salt, drought, pesticide, temperature, and metal stresses [15].

Endophytic bacteria are plant-associated bacteria that reside in the internal tissues of the plant without harming it [16]. The nature of their mutualistic association depends on their location in the plant tissue, either intercellularly or intracellularly [17]. The integral intracellular colonization by non-cultivable endophytic bacteria in the cytoplasm and cell wall-plasma membrane peri-space in bananas indicated a mutualistic association between the host and the endophytes. Bacteria colonizing the cytoplasmic space release bacterial metabolites directly to the protoplasm of the host, which could influence gene expression and functioning of the host [18]. Endophytes have been isolated from various species of plants and organs and have mostly been recruited from the rhizosphere of the host plants. Endophytes had been observed to enter host plants through roots and colonize intercellular spaces of the roots [19].

Root endophytic bacteria have different functions, adaptations, specialization, and competence [20]. As these root-endophytes inhabit the localized point of entry or spread within the plant, they produce several bioactive metabolites and hydrolytic enzymes to endure in the environment of the host plant. Mechanisms by which root-endophytes survive with the changing environmental conditions could contribute to better growth, health, and development of the host plants [21]. Root-endophytes possess at least one, or some of the mechanisms of the following functions: (i) production of phytohormone, (ii) biological control of phytopathogens, (iii) supply nutrients nitrogen or phosphate for plants [22]. Their ability to reduce stress ethylene by the synthesis of 1-aminocyclopropane1-carboxylate (ACC) deaminase, production of siderophores, and phosphate solubilization may also contribute to the growth and development of plants [23]. Application of diazotrophic endophytic bacteria could provide nitrogen, as the interior of the plant has direct accessibility of the fixed nitrogen to the plants [24].

Intracellular endophytic bacteria (Pseudomonas fluorescens SLB4-P, Pseudomonas sp. SLB6, and Pseudomonas sp. SY1) isolated from Phragmites australis were found to improve seedling development, root and shoot growth, and stimulated the formation of root hair when inoculated on rice, Bermuda grass, and annual bluegrass. Pseudomonas sp. strain SY1 was found to reduce Fusarium oxysporum infection in all three host plants [25]. Fluorescentlabeled non-pathogenic and non-symbiotic Escherichia coli Bl21 and Saccharomyces cerevisiae had demonstrated that they move in the root cells of Arabidopsis thaliana and tomato plants, which could take up these microorganisms into the root cells [26]. Endophytic bacterial communities associated with three varieties of papaya (Arka Surya, Arka Prabhath, Red Lady) were found to be highly diverse with several common phyla, where bacteria were found to be more abundant in the cytoplasmic matrix. The shoot tips of papaya seedlings harbored a variety of bacteria, which was attributed to their intracellular inhabitation. Activation of originally uncultivable microorganisms to cultivation in papaya stocks showed bacterial growth of Bacillus (35\%), Methylobacterium (15\%), and Pseudomonas $(10 \%)$. Functional analysis of metabolically active intracellular endophytes also indicated their roles in different plant processes and pathways [27]. Variety of plant species are associated with the diversity of cultivable bacterial endophytes, with most of the members 
belonging to soil bacterial genera such as Azospirillum, Bacillus, Burkholderia, Enterobacter, and Pseudomonas [28]. Microorganisms having PGP and biocontrol potential are used in integrated nutrient and disease management. Moreover, future commercialization and use of bio-inoculants in the agricultural sector as an eco-friendly alternative tool will help to improve crop yield as well as the economy.

\section{Rhizosphere and Root Endophytes}

The term "rhizosphere" was first defined by Lorenz Hiltner in 1904 as the region of soil closely associated with plant roots [29]. The term 'rhizobacteria' suggests the gathering of rhizospheric microbes around the plant root surfaces [30]. Bacteria inhabiting the rhizosphere are the source of the formation of endophytic bacterial communities, and in plants, roots have the highest occurrence of endophytic bacteria [31]. Endophytic bacteria are located in intra- and inter-cellular regions or the vascular tissue and colonized aerial parts or roots [32]. Bacteria make entry to plant tissues especially through lateral roots or root hair cells. The entry of endophytic bacterium Enterobacter asburiae JM22 in cotton plants was assisted by its ability to hydrolyze plant cell wall-bound cellulose [33]. Root endophytes colonize and penetrate the epidermis of the lateral root below the root hair zone and in root cracks. They have the potential to establish populations both inter-and intracellularly [34]. Interaction of host plants with endophytes is facilitated by bacterial motility, or by the growth of the roots that allow passive colonization. A shift in cellular and molecular levels that occurs during the development of plants [35] may also affect the endophytic colonization. The enzymatic mechanisms have key roles in enabling the endophytic microorganisms to penetrate the plants, which could later be transmitted by seed [31]. The plant root not only provides the mechanical support and nutrients uptake for the plants but also incorporates, accumulates, and emits different types of chemical compounds in form of root exudates [36]. These root exudates act as a chemoattractant for a diverse group of soil microbial communities. The exudation of a diverse group of chemical compounds regulates soil microbial communities by changing soil physical and chemical properties [37]. Additionally, microbial interactions in the rhizosphere influence the rooting pattern and also enhance the supply of accessible supplements to plants [38]. The microbes utilize the root exudates in the rhizosphere as carbon and nitrogen sources. In return, plants take up organic molecules for their growth and development, derived by microbes [39]. The microbial communities might secure up to $15 \%$ of the root surface, as they also have the metabolic flexibility to adjust the quality and quantity of the root exudates for their use [40]. The components of exudates can be named allelochemicals, phytotoxins, phytoalexins, phytohormones, and/or ectoenzymes. The measures of exudates vary in the plant to plant, plant growth cycle, and rooting pattern [37].

\subsection{Root Endophytes as Plant Growth-Promoting Rhizobacteria (PGPR)}

Kloepper and Schroth [41] proposed "Plant growth-promoting rhizobacteria (PGPR)" as a group of rhizospheric bacteria that colonizes around the plant roots and enhances plant growth. The PGPR attached to the surface of plant roots is termed as extracellular PGPR. At the same time, PGPR that is localized inside the plant cells and produces nodules are known as intracellular PGPR [42]. Around 2 to $5 \%$ of rhizospheric bacteria belong to the group of PGPR [43]. The majority of the PGPR belong to the genera of Acinetobacter, Arthrobacter, Azospirillum, Azotobacter, Bacillus, Bradyrhizobium, Burkholderia, Caulobacter, Chromobacterium, Enterobacter, Erwinia, Flavobacterium, Frankia, Klebsiella, Micrococcus, Pseudomonas, Rhizobium, and Serratia [41].

In the past decade, several studies have been done to understand the functions within the rhizosphere, as it is an ecological niche for microbes that now receives much more attention due to its prospects in the development of sustainable agricultural practices. PGPRs have emerged as sustainable devices for the improvement of farming frameworks. PGPR improves plant growth and development in three ways, i.e., synthesizing specific compounds for the plants, encouraging the take-up of particular supplements from the 
soil, and decreasing the activity of disease-causing microbes [44]. The PGPR may impact the plant development directly by fixing environmental nitrogen, solubilizing insoluble phosphates, secreting phytohormones, for example, indole acetic acid (IAA), gibberellic acid (GA), and ACC (1-Aminocycloprapane-1-carboxylic acid) deaminase synthesis, which helps in the regulation of ethylene biosynthesis while also indirectly helping siderophore production, induced systemic resistance (ISR), and the production of antifungal metabolites (for example, antibiotics) to suppress the infectious microbes. Rhizospheric bacteria had been reported to enhance growth in several crop plants such as rice, wheat, maize, pea, etc., by colonizing the rhizosphere [45]. Some of the endophytes and their beneficial interaction with the host plants have been summarized in Table 1.

Table 1. Association of endophytes with respective host plants and their beneficial attributes for plant growth promotion.

\begin{tabular}{|c|c|c|c|c|}
\hline S1. No. & Endophyte & Host-Plant & PGP-Attributes & Reference \\
\hline 1. & $\begin{array}{l}\text { Paenibacillus polymyxa } \\
\text { SK1 }\end{array}$ & Lilium lancifolium & $\begin{array}{l}\text { 1-Aminocycloprapane-1-carboxylic acid (ACC), } \\
\text { deaminase, indole-3-acetic acid (IAA), siderophores, } \\
\text { nitrogen fixation, and phosphate solubilisation, } \\
\text { showed antifungal activities against plant pathogens }\end{array}$ & [46] \\
\hline 2. & $\begin{array}{c}\text { Paenibacillus } \\
\text { glycanilyticus LJ121 and } \\
\text { Pseudomonas } \\
\text { brenneri LJ215 }\end{array}$ & Lupine root & $\begin{array}{l}\text { Increase shoot } \\
\text { Dry weight, number of nodules per } \\
\text { plant, photosynthetic assimilation } \\
\text { rate and chlorophyll a and b content and } \\
\text { shoot nitrogen and phosphorus content }\end{array}$ & [47] \\
\hline 3. & $\begin{array}{l}\text { Arthrobacter sp. } \\
\text { EpS/L16 }\end{array}$ & Echinacea purpurea & IAA production, increase in the number of leaves & {$[48]$} \\
\hline 4. & $\begin{array}{l}\text { Lysinibacillus sp. S24 } \\
\text { Brevibacterium sp. S91 }\end{array}$ & Tea (Camellia sinensis L.) & $\begin{array}{c}\text { Highest phosphate solubilisation, IAA and ammonia } \\
\text { production }\end{array}$ & [49] \\
\hline 5. & Enterobacter cloacae R7 & Maize roots & $\begin{array}{c}\text { IAA (35.4 mg mL_1), ACC deaminase }(+), \\
\text { siderophore }(+) \text {, and phosphate solubilization }(+), \\
\text { alleviating heavy metal stress }\end{array}$ & {$[50]$} \\
\hline 6. & Bacillus cereus N5 & Maize roots & $\begin{array}{l}\text { IAA (47.3 mg mL_1), ACC deaminase }(+), \\
\text { siderophore }(+) \text {, and phosphate solubilization }(+), \\
\text { tolerance of this plant to environmental stresses }\end{array}$ & {$[50]$} \\
\hline 7. & $\begin{array}{l}\text { Streptomyces exfoliatus } \\
\text { FT05W }\end{array}$ & Lettuce roots & $\begin{array}{l}\text { solubilize phosphates and to synthesize IAA, active } \\
\text { against other soil borne fungal pathogens }\end{array}$ & [51] \\
\hline 8. & $\begin{array}{l}\text { Stenotrophomonas } \\
\text { rhizophila ep-17 }\end{array}$ & Soybean & $\begin{array}{c}\text { Beneficial association with Bradyrhizobium in the } \\
\text { rhizosphere and promote plant growth, nutrient } \\
\text { uptake and grown soybean under salt stress } \\
\text { condition. }\end{array}$ & {$[52]$} \\
\hline 9. & $\begin{array}{l}\text { Bacillus subtilis SU47 } \\
\text { and Arthrobacter sp. } \\
\text { SU18 }\end{array}$ & Wheat & $\begin{array}{l}\text { Showed an increase in dry biomass, total soluble } \\
\text { sugars and proline content }\end{array}$ & [53] \\
\hline 10. & $\begin{array}{c}\text { Bacillus pumilus 2-1, } \\
\text { Chryseobacterium } \\
\text { indologene 2-2, and } \\
\text { Acinetobacter johnsonii } \\
\text { 3-1 }\end{array}$ & Sugar beet & $\begin{array}{l}\text { Increased photosynthetic capacity, increased } \\
\text { concentration of carbohydrates }\end{array}$ & [54] \\
\hline 11. & $\begin{array}{l}\text { Burkholderia } \\
\text { phytofirmans } \\
\text { strain PsJN }\end{array}$ & $\begin{array}{l}\text { Potato, tomato, Onion, } \\
\text { maize, barley }\end{array}$ & ACC deaminase activity, IAA synthesis & [55] \\
\hline 12. & Pseudomonas syringae & $\begin{array}{l}\text { Arabidopsis } \\
\text { thaliana }\end{array}$ & IAA and abscisic acid biosynthesis & [56] \\
\hline 13. & $\begin{array}{l}\text { Gluconacetobacter } \\
\text { diazotrophicus }\end{array}$ & Sugarcane & Nitrogen fixation & [57] \\
\hline 14. & $\begin{array}{l}\text { Rhizobium } \\
\text { leguminosarum bv. } \\
\text { trifolii }\end{array}$ & $\begin{array}{l}\text { Rice } \\
\text { roots }\end{array}$ & Biological $\mathrm{N}_{2}$ fixation & [58] \\
\hline
\end{tabular}

Rhizospheric bacteria and endophytic bacteria may utilize similar mechanisms to promote plant growth promotion. The main difference is that endophytic bacteria are not 
exposed to uncontrolled changes in soil conditions. Variations in soil $\mathrm{pH}$, temperature, and water content may hinder the proliferation of rhizospheric bacteria and existing soil bacteria may compete for binding sites on the root surfaces of the host plants [7]. Moreover, the use of endophytic bacteria could facilitate the growth of the plants in agriculture, horticulture, silviculture, and also to remove pollutants from the environment, as they are more persistent [59]. PGPR modifies the chemical composition of root cell walls that might allow their progression between root cortex cells and act as endophyte [60]. Such modifications of root cell wall ultrastructure are mainly PGPR generated changes in plant gene expression. Rice roots inoculated with endophytic PGPR Azospirillum irakense were observed to increase the expression of polygalacturonase genes [61].

\subsection{Mode of Action of Endophytic PGPR}

PGPR can enhance plant growth by employing one or more of these mechanisms (Figure 1).

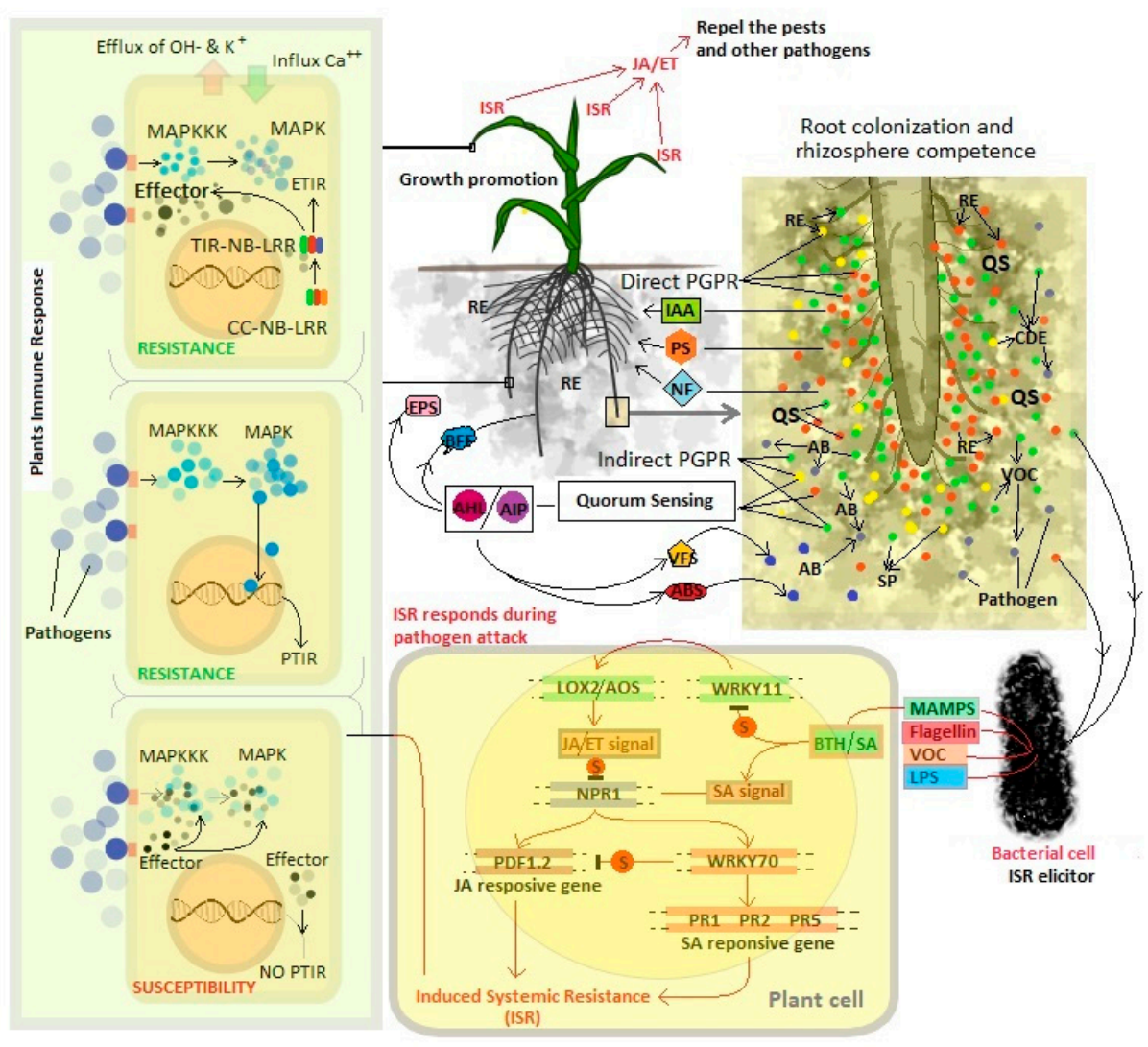

Figure 1. Microbial interactions at the root zone, and cellular responses of the host plant. Abbreviations: JA/ET-Jasmonate/Ethylene, SA-Salicylic acid, AB-Antibiotic, ABS-Antibiosis, RE-Root exudates, VOCs-Volatile organic compounds, VFS—Virulence factor secretion, CDECell wall degrading enzymes, BFF-Biofilm formation, PS-Phosphate solubilization, SPSiderophore production, NF-Nitrogen Fixation, QS-Quorum sensing, BTH-Benzothiadiazol, LPS—Lipopolysaccharide, IAA — Indole acetic acid, S-Suppression, PTIR-Pathogen Triggered Immune Response, NB—Nucleotide binding, CC—Coiled coil, LRR—Leucine rich repeats.

\subsubsection{Direct Mechanism} Nitrogen-Fixation

The nitrogen inadequacy in soil vis-a-vis demand for agri-products has prompted the use of enormous amounts of nitrogenous chemical fertilizers to accomplish the targets of yield. Plants assimilate nitrogen mostly in the form of ammonia. A wide variety of nitrogen-fixing bacteria have been recognized, which restore nitrogen symbiotically with 
specific plants (primarily legumes). Examples of symbiotic nitrogen fixers are Rhizobium, Sinorhizobium, Azorhizobium, Allorhizobium, Mesorhizobium, Bradyrhizobium, Frankia, Azoarcus, Achromobacter, Burkholderia, and Herbaspirillum [45]. Ammonia production by PGPR is an important feature that indirectly contributes to plant growth. PGPR strains belonging to Bacillus, Pseudomonas, and Serratia had been reported to produce ammonia [62]. Deamination or ammonification processes are carried out by complex nitrogenase enzymes. Nitrogenase (nif) genes involved in nitrogen fixation require structural as well as regulatory genes. The structural genes involved in Fe protein activation, biosynthesis of Fe-Mo cofactor, and donation of electrons while regulatory genes regulate the synthesis and function of enzymes [63]. Rhizobia act as endophytes in nodules that promote plant growth and isolation of endophytic rhizobia from nodules of Vicia were classified into Ensifer, Shinella, and Rhizobium tropici [64]. Nitrogen-fixing endophytes of the Rhizobiaceae family have been observed to have a unique symbiotic relationship with their host plants [65]. Rhizobial endophyte Azorhizobium caulinodans ORS571 secreted cellulases and pectinases, which help the bacteria in colonizing the xylem elements of Sesbania rostrata, in the process of nodule formation. It indicated that vascular rhizobial endophytes could be symbiotic, and provide fixed nitrogen to their host plants, and that xylem elements are the sites for nitrogen fixation by diazotrophs, as xylem serve as a site for the metabolites exchange, which is essential for nitrogen fixation [57]. Endophytic bacterium Gluconoacetobacter diazotrophicus (Acetobacter diazotrophicus) could fix nitrogen in sugarcane [66]. Endophytic diazotrophs Azoarcus increased nitrogen fixation in kallar grass and increased the productivity of non-legumes including cash crop plants [67]. Azoarcus spp. were found to be more abundant in rice roots expressing high levels of nitrogenase in the aerenchyma to indicate the location within the roots [68]. The process of nodulation and $\mathrm{N}_{2}$-fixation by endophytic rhizobia has been well studied and there are several excellent reviews available [69-71], and it is therefore not elaborated here (Figure 1).

\section{Solubilization of Phosphate}

Phosphorus $(\mathrm{P})$ is the second most important element, supplemented to soil for plant growth, after nitrogen. This low accessibility of phosphorus to plants is due to its insoluble forms in soil. In contrast, plants assimilate it just in two soluble ways, i.e., monobasic $\left(\mathrm{H}_{2} \mathrm{PO}_{4}\right)$ and the dibasic $\left(\mathrm{HPO}_{4}\right)$ ions of phosphate [72]. To overcome P insufficiency in soils, there are extensive uses of phosphate fertilizers in farming fields. Plants retain low measures of applied phosphate fertilizers, and the rest are quickly changed over into insoluble forms in the soil. The regular use of phosphate fertilizers is not only expensive but also environmentally undesirable [39]. The microbes, having phosphate-solubilizing activity termed phosphate-solubilizing microorganisms (PSM), may provide the accessible phosphate for the plants [73]. There are different PGPR genera such as Serratia, Pseudomonas, Rhizobium, Bacillus, Azotobacter, Burkholderia, Enterobacter, Bradyrhizobium, Streptomyces, Cladosporium, etc., which are the most efficient phosphate-solubilizing PGPR [74]. PGPR employs different mechanisms to solubilize the insoluble phosphates. One of the critical mechanisms is the production of organic acids during sugar metabolism. The rhizosphere inhabiting PGPR exploits the sugars of plant root exudates and releases various organic acids. It creates an acidic condition by lowering the $\mathrm{pH}$, and then the organic acids act as chelating agents and release phosphates from insoluble phosphate compounds. The synthesis of phosphatases by PGPR also mineralizes phosphates from the organic phosphatic substances [39].

Endophytes had been known to increase the availability of phosphorus to the plant through phosphorus solubilization. The release of low molecular weight acids enables the chelation of metal cation attached to phosphorus and creating easily accessible to plants [75]. Endophytic isolates Achromobacter xiloxidans and Bacillus pumilus were characterized for phosphate solubilizing abilities in sunflower [76]. Endophytic bacteria isolated from soybean can assimilate phosphate [77]. Oteino et al. [78] described the genetic systems of endophytic strains that can solubilize phosphate and observed that Pisum sativum L. plants 
treated with endophytic strains showed a significant increase in plant growth parameters. Five Pseudomonas strains were able to solubilize tricalcium phosphate $\left[\mathrm{Ca}_{3}\left(\mathrm{PO}_{4}\right)_{2}\right]$ to the level of $>400 \mathrm{mg} \cdot \mathrm{L}^{-1}$ while Bacillus showed poor solubilization in their study. Three Pseudomonas strains (L111, L288, and L321) were observed to possess pqq gene clusters ( $p q q F A B C D E$ ) and $g c d$ and $g a d$ genes for phosphate solubilization. The presence of $p q q$ genes in association with the $g c d$ gene confirmed that the strains could produce gluconic acid, which is the main mechanism for phosphate solubilization.

\section{IAA Production}

IAA (a type of auxin) is known for its role during the various developmental stages of plants such as cell division, cell elongation, and tissue differentiation. IAA is produced by multiple strains of bacteria that are known for their plant growth-promoting activity [79]. PGPR strains help plants to uptake nutrients, increase root size, length, and biomass as they have a close association with root and root-soil $[80,81]$. Endophytic bacteria including Bacillus aryabhattai, B. subtilis, Klebsiella pneumoniae, Microbacterium trichotecenolyticum, and Paenibacillus kribbensis were reported to produce IAA [82]. Tryptophan is the natural exudate from the roots of the plants, and it is the main precursor for the biosynthesis of IAA. Several pathways using tryptophan as a precursor for IAA syntheses such as indole-3-acetamide (IAM), indole-3-pyruvate (IPyA), tryptamine (TAM), tryptophan sidechain oxidase (TSO), and tryptophan independent pathways have been reported [79]. The PGPR, having the IAA production ability, might have multiple roles in different kinds of plant-bacteria communications, during plant development, and root nodulation [83]. The amount of IAA produced by different endophytic bacteria and plants affect their interaction [84] (Figure 1). Microbial regulation on the IAA signaling system has been considered as the key mechanism that enhances lateral root development and relieves plant stress [7]. Endophytes that excessively produce IAA have exhibited transcriptional variations in nitrogen-fixing nodules [85]. They could increase the expression of the nifH gene, which leads to higher nitrogenase activity in rice plants [86]. IAA producing the traits of endophytic bacteria could increase the cadmium metal uptake in the root cell wall and alleviated metal toxicity by translocation from root to shoot in Arabidopsis [87]. Endophytic bacteria identified as B. aryabhattai $\mathrm{MBN} 3$, B. megaterium $\mathrm{MJHN} 1$, and B. cereus MJHN10 were found to produce IAA through a tryptophan dependent pathway. In-vitro application of the isolates in the plant roots was observed to increase the numbers of lateral roots and enhance root length [88]. Endophytic bacteria isolated from terrestrial orchids were observed to produce IAA and stimulated root development and root length in kidney beans [89]. Besides, bacterial IAA expands root surface territory and length, allowing the plant to take-up better supplements and improve plant growth [90]. It was also considered that IAA production is an effective tool for the detection of beneficial microbes with the potential for plant growth promotion [91]. Plant growth-promoting endophyte Bacillus sp. SLS18 produced IAA, siderophores, and ACC deaminase and increased the biomass of sweet sorghum (Sorghum bicolor L.), Phytolacca acinosa Roxb. and Solanum nigrum L. in presence of $\mathrm{Mn} / \mathrm{Cd}$, as the strains showed resistance to heavy metals [92]. Seeds of Azadirachta indica A. Juss (Meliaceae) treated with three endophytic Streptomyces strains AzR-051, AzR-049 and AzR-0109 were observed to promote growth and antagonized the growth of Alternaria alternate, which is the causal agent of early blight disease of tomato plants. The strains AzR-051, AzR-049, and AzR-0109 were found to produce IAA at $13.73 \mu \mathrm{mol} \mathrm{mL}^{-1}, 9.22 \mu \mathrm{mol} \mathrm{mL}^{-1}$, and $10.43 \mu \mathrm{mol} \mathrm{mL}^{-1}$ respectively [93]. The cultivable rice seeds endophytes exhibited promising plant growth-promoting activities, which were observed to be dominated by Proteobacteria of the class Gamma-proteobacteria [94]. Plant growth-promoting endophytic bacterium, Sphingomonas sp. LK11 isolated from Tephrosia apollinea leaves produced IAA $(11.23 \pm 0.93 \mu \mathrm{M} / \mathrm{mL})$ and exhibited physiological active gibberellins $\left(\mathrm{GA}_{4}: 2.97 \pm 0.11 \mathrm{ng} / \mathrm{mL}\right.$ ) and inactive gibberellins (GA9: $0.98 \pm 0.15 \mathrm{ng} / \mathrm{mL}$; $\mathrm{GA}_{20}: 2.41 \pm 0.23 \mathrm{ng} / \mathrm{mL}$ ) [95]. Type strains belonging to Flavobacterium sp. were found to 
be IAA producers and phosphate solubilizers with tolerance to high salt concentration and osmotic stress [94].

\section{1-Aminocyclopropane-1-carboxylate (ACC) Deaminase}

Ethylene is a vital plant phytohormone that facilitates plant growth and development under non-stressed conditions. However, under stressed conditions, the level of ethylene increases and negatively regulates plant growth. It restricts the elongation of root and transport of auxin, supports aging and extirpation of organs, and assists in the ripening of fruits. Ethylene plays a key role in the activation of plant defense against biotic stresses [96]. 1-Aminocyclopropane-1-carboxylate (ACC) is the primary precursor in plants for ethylene synthesized by ACC synthase by converting S-adenosyl methionine. Under stressed conditions, the activity of ACC synthase increases and produces a high amount of ethylene [81]. When the ACC is degraded by the ACC deaminase producing bacteria, the level of ethylene decreased, which results in the elongation of roots [7,97]. A diverse group of PGPR having ACC deaminase activity has been reported as Serratia, Pseudomonas, Bacillus, Acinetobacter, Rhizobium, etc. [39]. This PGPR with ACC deaminase activity hydrolyses the primary precursor ACC to $\alpha$-ketobutyrate and ammonia and reduces the ethylene level and improves plant health under stressed conditions [98]. ACC deaminase is a stress release enzyme, as it alleviates different types of biotic and abiotic stressors such as pathogenic attacks, drought, metal, radiation, salt, heat stress, etc. [6].

Endophytic microorganisms with the ability to utilize ACC as the nitrogen source could reduce the level of ACC and ethylene that led to the prevention of ethylene mediated plant growth inhibition. Physiological and molecular characterization of endophytic bacteria such as Enterobacter, Klebsiella, and Pseudomonas, with the ability to produce ACC deaminase, have been reported $[99,100]$, and genes responsible for its production have been isolated and expressed from Klebsiella sp. [101]. Treatment with Azospirillum brasilense Sp245 expands the ABA content in Arabidopsis thaliana [102]. A study conducted by Rashid et al. [103] isolated a total of 174 bacterial endophytes from internal tissues of tomato plants, and 25 strains were observed to possess ACC deaminase activity with intracellular levels ranging from 0.43 to $12.50 \mu \mathrm{mol}^{-1} \mathrm{~g}^{-1} \mathrm{~h}$. The strains identified as Pseudomonas spp. showed higher ACC deaminase activity while Microbacterium spp., Bacillus spp., Agrobacterium spp., exhibited higher levels of IAA and siderophore.

\section{Role of Bacteria in Root System Architecture (RSA), and Its Modification}

To assist growth, different types of plants enhance their root arrangement to transverse soil and obtain nutrients. The root is an integral part of plants comprising distinct regions, for instance, the tip of the root, meristem of the root, elongation region, and emerging oblique roots [104]. Different regions of the root perform differently. The root hairs are epidermal cells essential for mineral nutrition in a plant $[105,106]$. In Fabaceae, the root tip is the crucial section to initiate the process of colonization of rhizobia, which ultimately triggers root nodule emergence [107]. In the case of Poaceae, PGPR colonizes the oblique roots and root hairs where they illustrate the resources that are plant favorable [108]. RSA includes topography of root arrangement, primary and oblique roots distribution, and the amount and realm of several roots. RSA holds an impact on the various biotic and abiotic agents, involving plant growth-promoting bacterial strains. PGPR, along with their interference with plant hormonal balance, remodel RSA, and root tissue structure. PGPR modifies the chemical configuration and the structure of the cell wall of the root. For instance, Bacillus pumilus INR-7, which is a biocontrol agent, can magnify the deposition of lignin in epidermal tissues of pearl millet [109]. B. pumilus SE34 and B. subtilis UMAF6639 triggered a similar reaction when injected into the roots of pea and melon. After analysis, it was concluded that the root injected with Azospirillum lipoferum CRT1 had high lignin content compared to the uninjected ones. In the root cell wall, pectate is lowered by pectate lyases, which is synthesized by Azospirillum irakense. It shows promotion between the cortexes of roots and behaves as an endophyte [60]. B. subtilis GB03 encourages the growth of Arabidop- 
sis growth by forming VOCs, which regulates the expression of 38 genes [110]. Out of them, 30 were involved in the extension of the cell wall. The expression of polygalacturonase genes injected in rice roots is stimulated by the $A$. irakense [61].

RSA is also affected when PGPR, having the ability to produce plant-hormones, invade or colonize root tissues [111]. For the plant organogenesis and root shape architecture, the equilibration between phytohormones such as auxin and cytokinin is an essential regulator [112]. Endophytic bacteria affect the auxin to cytokinin ratio because they create a broad span of plant hormone and induce phytohormones and subsidiary metabolite, which inhibits the pathway of plant auxins such as 2,4-diacetylphloroglucinol and nitric oxide. The auxin formed by many plant-associated bacteria is indole-3-acetic acid [79]. In the growth and development of a plant, extrinsic IAA controls a diverse variety of processes such as primary root elongation, which is supported by the low concentration of IAA, whereas the formation of oblique roots decreases the length of the root and expands root hair establishment, which is stimulated by the high concentration of IAA. Azospirillum brasilense can reduce nitrate, which ultimately generates NO during the colonization of roots [109]. Lateral root formation is controlled by NO, which is intricate in the pathway of auxin signaling. DAPG acts as an indicating molecule for systematic resistance incited plants [113], inciting exudation of roots [114], and strengthening the branching of roots. The inoculation of bacteria may have an effect on auxin signaling pathways and lateral root response of the host plant. In Arabidopsis, inoculation of Phyllobacterium brassicacearum STM196, a low-IAA producer, triggered changes in IAA distribution in plant tissues, which was independent to IAA released by bacteria itself [115]. Cytokinin production (especially zeatin) has been observed in root-associated bacteria such as Arthrobacter, Pseudomonas fluorescens, etc. [116,117]. It supports plant cell division, and also influences the multiplication of root hairs, and controls the differentiation of root meristem.

\subsubsection{Indirect Mechanisms}

Siderophore Production

Iron is one of the most abundant minerals found on the earth's surface. It is classified as a micronutrient yet is not easily available for plants. Iron is usually present in nature as $\mathrm{Fe}^{3+}$, which is exceptionally insoluble; to take care of this issue, PGPR releases siderophores [118]. Siderophores are low atomic weight compounds that chelate ferric iron $\left(\mathrm{Fe}^{3+}\right)$. Microbial siderophores facilitate the Fe supply to plants in iron deficit conditions and improve plant growth [119] (Figure 1). Under $\mathrm{Fe}^{2+}$ limited conditions, microbial siderophores form complexes with Fe containing minerals or organic compounds, which is then taken up by microbial cells where $\mathrm{Fe}^{3+}$ is converted and released as $\mathrm{Fe}^{2+}$ [120]. Siderophoreproducing PGPR restricts the growth of several plant pathogens, by creating a competitive, iron-limiting environment [121]. The metal stress condition induces microbial siderophore production in the rhizosphere. It has been observed that under a heavy metal stressed condition, plants experience iron deficiency and microbial siderophore helps the plants to maintain sufficient $\mathrm{Fe}^{2+}$ condition [39]. Bacterial siderophore production may be influenced by the presence of heavy metals, and plants could reduce heavy metal-toxicity by improving iron supply to the plants [122]. In addition to iron, siderophore could form stable complexes with heavy metals, which lead to an increase in the soluble metal concentration and thus bacterial siderophores assist in alleviating plant stress [123]. Endophytic bacteria such as Methylobacterium mesophilicum and Sphimgomonas spp. were found to be resistant to nickel $(\mathrm{Ni})$, as their endophytic lifestyle ensure survival in low levels of free iron content in the plant tissue [124]. Siderophore producing Lead $(\mathrm{Pb})-$ resistant endophytic Pseudomonas fluorescens G10 and Microbacterium sp. G16 inoculated in Brassica napus were found to increase $\mathrm{Pb}$ uptake into the shoots and enhanced $\mathrm{Pb}$ availability in B. napus [125].

Pseudomonas fluorescens spp. is an efficient iron $\left(\mathrm{Fe}^{3+}\right)$ competitor that produces two types of siderophore-pyoverdine (fluorescent pigment) and pyochelin (non-fluorescent pigments) [126]. Endophytic actinomycetes can promote plant growth and have fungicidal properties for Pythium diseases in cucumber [127] and wheat [128]. Further, Pseu- 
domonas putida B10 help by suppressing the growth of Fusarium oxysporum by siderophore production in the soil [129]. In addition, endophytic bacteria that produce siderophore could restrict the growth of plant pathogens as they create an iron-limiting microenvironment [130]. Jasim et al. [100] studied the endophytic bacterial isolates of ginger, and the isolates ZoB1 (Bacillus sp.), ZoB2 (Pseudomonas sp.), and ZoB3 (Stenotrophomonas sp.) that produced siderophore. Bacillus sp. had been reported to produce petrobactin type of siderophore [119]. Pseudomonas sp. had been described to produce more than 50 structurally related siderophores including pyoverdins [131]. Genome sequencing of Strenotrophomonas maltophilia have shown its capability to produce catechol type of siderophore compound enterobactin [132]. Siderophores were observed to be efficiently produced by rice seed's endophytic Pseudomonas strains [94].

\section{HCN Production}

HCN producing PGPR act as biocontrol agents by showing harmful effects against the plant-parasitic microbes [95]. The benefits of $\mathrm{HCN}$ production in bacteria itself are not clear to date, but the role of $\mathrm{HCN}$ against the fungal attack in plants has been reported in several PGPR strains [133]. Rhizospheric plant beneficial microbes with $\mathrm{HCN}$ production ability have a significant role in plant protection against several plant diseases. Certain endophytes such as Bacillus produce HCN in avocado and black grapes [134] and HCN produced by Pseudomonas putida revealed antibacterial activity against Escherichia coli and Klebsiella pneumoniae and antifungal activities against Pythium ultimum [134]. Endophytic bacteria identified as Pseudomonas and Serratia, isolated from within the tissues of various plants revealed improvement in seed germination, seedling length, and plant growth of oilseed rape and tomato. Seeds treated with endophytes were observed to reduce disease symptoms caused by vascular wilt pathogens Verticillium dahlia Kleb and Fusarium oxysporum f. sp. lycopersici (Sacc.). Endophytic isolates were observed to produce microbial inhibitory volatile compounds and $\mathrm{HCN}$ that could suppress plant pathogens. In addition, endophytes residing in the vascular tissue (conductive tissue) produce induced resistance, which enables them to inhibit soil-borne pathogens that are colonized in the vascular tissue of a plant [135].

\section{Cell Wall Degrading Enzymes}

It has been contemplated that numerous PGPR integrate extracellular hydrolytic enzymes that are engaged with the degradation of fungal cellular components, for example, chitin, hemicellulose, cellulose, proteins, and DNA [136]. Secretion of hydrolytic enzymes by endophytes appears to be important for colonizing the plant roots [137]. The capability of the endophytes to release lytic enzymes facilitates the hydrolysis of a wide range of polymeric compounds including chitin, proteins, cellulose, hemicellulose, and DNA [138]. When endophytes colonize on the plant surface, they produce enzymes that could hydrolyze the plant cell wall. Further, the hydrolytic enzymes produced by endophytes have the capability of repressing plant pathogens directly by degrading cell walls of fungi and oomycetes [139]. Endophytic bacterial colonization in the plant tissues occurs through migration along with intercellular spaces by secreting cell-wall degrading enzymes such as cellulases and pectinases [20]. The cell wall of fungi (except for oomycetes) is composed of chitin [139]. The capability of hydrolytic enzymes produced by PGPR to break down the glycosidic bonds of chitin gives it immense importance as a biocontrol agent [140]. The lytic activity of the hydrolytic enzymes on the fungal cell wall, hyphal tip, and germ tube cause hyphal swelling, twisting, and bursting of the hyphal tip leading to fungal death. Among the immense number of hydrolytic catalysts, chitinase, protease, glucanase, and cellulase are significant because of their capacity to degrade and lyse the cell wall of fungal parasites [138]. Cell degrading enzymes of rhizobacteria harm the basic structure of the cell wall of phytopathogens (Figure 1). Various PGPR strains (including endophytes) belonging to the genera of Serratia, Pseudomonas, Rhizobium, Bacillus, Azotobacter, Burkholderia, Enterobacter, Bradyrhizobium, Streptomyces, Cladosporium, etc., can secrete hydrolytic 
enzymes for the biocontrol of plant fungal pathogens such as F. oxysporum, R. solani, $P$. ultimum, S. rolfsii, etc. [141,142]. Plant-beneficial endophytic bacteria including members of Enterobacter, Pseudomonas, Burkholderia, Bacillus, and Azospirillium have been identified from various plant species that act as biocontrol agents [143].

Hydrolytic enzymes (chitinase, protease, glucanase, and cellulase) secreted by PGPR are responsible for the lysis of fungal pathogens during hyperparasitism [144]. Some of the PGPRs, such as Serratia sp. [145], Pseudomonas [146], Paenibacillus sp. [147] are also biocontrol agents (BCAs), which release hydrolytic enzymes, and are utilized in the biocontrol of phytopathogens [148]. Endophytic PGPR Streptomyces anulatus S37 isolated from wild Vitis vinifera was found to confer resistance against Botrytis cinerea pathogen [149]. Mutational inactivation of 1,3-glucanase gene in Lysobacter enzymogenes showed a reduction in biocontrol activity toward Pythium damping-off disease in sugar beet and bipolaris leaf spot of tall fescue [150]. Lytic enzymes produced by endophytic Streptomyces revealed a strong effect on antagonizing cacao witches broom disease [151], found to affect inter/intracellular colonization [152].

\section{Antibiotic Production}

The production of a diverse group of antibiotics is one of the significant PGP characteristics, restricting plant parasites, particularly fungi [153]. The use of PGPR for controlling infection in agricultural plants has been proposed as an alternative way for chemical pesticides. Pyrolnitrin secreted by Pseudomonas species and Burkholderia exhibited antagonism against a wide range of fungi belonging to the group of Ascomycetes, Basidiomycetes, and Deuteromycetes, including some of the phytopathogens such as Botrytis cinerea, Rhizoctonia solani, Sclerotinia sclerotiorum, and Verticillium dahliae [154]. Similarly, 2,4diacetylphloroglucinol (2,4-DAPG), a polyketide antibiotic produced by several microbes, shows antibacterial, antifungal, antihelminthic, antiviral, as well as phytotoxic effects [155]. Some endophytic strains of Pseudomonas have shown their ability to synthesize chemicals such as phenazine that enhance the growth of the host plant [156]. Phenazines (phenazine1-carboxylic acid, PCA; 2-hydroxyphenazine-1-carboxylic acid; and 2-hydroxyphenazine), a diverse group of antibiotics, show antagonisms against a diverse group of phytopathogenic fungi, gram-positive, as well as gram-negative bacterial pathogens [157]. PGPR belonging to the genera of Bacillus also produce a diverse group of antimicrobial metabolites such as subtilisin A, subtilin, TasA, and sublancin, which are derived from the ribosome or the non-ribosomal peptide and/or polyketide synthetases (NRPSs/PKS) Several antibiotic coding genes have been identified in Bacillus amyloquefaciens FZB42, and Bacillus subtilis 168 , which are $a c t, b a c, b a e, b m y, d f n, d h b, f e n, m l n$, and $s r f$, biosynthesized by the NRPSs and PKS enzymes [36].

Endophytes produce natural products such as alkaloids, flavonoids, terpenoids, steroids-natural products that are antibiotics, biological control agents, anticancer agents, and other bioactive compounds [158]. Endophytic bacteria produce signals that could mediate crosstalk with the host and lead to develop resistance against infections [159] (Figure 1). Endophytic Streptomyces sp. isolated from vine Monstera sp. produced a complex novel peptide antibiotic with activity against pythiaceous fungi and Cryptococcus neoformans, which is a human fungal pathogen [160]. Endophytic Bacillus sp. have been described to possess antifungal activities against plant pathogens. Endophytes isolated from older balloon flower plants antagonize Phytophthora capsii, Fusarium oxysporum, and Pythium ultimum [161].

\section{Volatile Organic Compounds Production}

Different types of volatile compounds (VOCs) are released by the plant-associated bacteria and their main function is to act as signal molecules and help in cellular-communications [162]. However, these VOCs have also been reported to restrict the growth of plant pathogens [163]. Different bacterial species, for example, Bacillus, Pseudomonas, Erwinia, Staphylococcus, etc., have been identified to produce 346 types of distinct volatile compounds [164]. Bacillus 
endophytes exhibited biocontrol activity by producing VOCs, which could protect plants directly against phytopathogens or indirectly by inducing plant resistance $[165,166]$ (Figure 1). VOCs emitted by Bacillus sp. were reported to modify root architecture, stimulate fresh weight, primary root length, and lateral root number and length on A. thaliana [167]. 2,3-butanediol produced by endophyte Enterobacter aerogenes was found to influence resistance to pathogens and herbivorous insects and disturbs tritrophic interactions [168]. It is found that after $96 \mathrm{~h}$ of disease induction in plants, the VOC's namely acetoin and 2, 3-butanediol reduce the growth pathogens under growth-chamber conditions [169]. Endophytic PGPR Bacillus subtilis strain DZSY21 was reported to inhibit the mycelia growth and conidial sporulation of fungal pathogen Curvularia lunata by producing VOCs like 2-methylbutyric acid, 2-heptanone, and isopentyl acetate. Application of VOCs in maize leaves was observed to reduce disease indexes from 60.52 to $26.64 \%$, further isopentyl acetate showed enhancement in accumulation of intracellular reactive oxygen species (ROS) in conidia [170]. VOCs (2,5-dimethylpyrazine and benzothiazole) produced by endophytic PGPR B. velezensis ZSY-1 was found to have strong antifungal activity toward Alternaria solani and Botrytis cinerea [171]. Moreover, fungal endophyte Muscodor albus produced VOCs including 2-butanone and 2-methyl furan, which have antibiotic properties [172]. Although more research is needed for further understanding of the volatile compounds, it is clear that VOCs work to enhance the plant's self-immunity.

\section{Role of Microbial Signals Modulate PGPR Functions}

\subsection{Regulation of Quorum Sensing by Plant-Associated Bacteria}

A population density-based phenomenon known as quorum sensing (QS) makes bacteria able to communicate by synthesizing small signaling molecules. Most widely studied are acyl-homoserine lactone (AHL) molecules produced by Proteobacteria, which move in and out of the cell either passively or actively. Signaling compounds involved in the QS process are called autoinducers [173]. In this process, Gram - ve bacteria use acyl-homoserine lactone (AHL), and Gram +ve bacteria use auto-inducing peptide (AIP) molecule as signaling molecules. The QS Process depends upon the cell density of bacteria. Plant growth and development are also improved by QS. PGPR colonization in the rhizosphere of the plant root exudates is also mentored by Quorum sensing [174]. In the colonization and biofilm formation process on the root surface, plant-associated bacteria used AHL biosensors to produce the AHL substances [175]. QS regulates the process of antibiosis, biofilm formation, exopolysaccharide production, virulence factors secretion, bioluminescence, sporulation, and competence process, in addition to the expression of many PGP attributes. PGPR may influence the cell-to-cell communications among itself and other bacteria and fungi, inhabiting and sharing the microenvironment of roots. This is facilitated through changes in the bacterial density by synchronizing gene expression [176], while some of the bacterial signals are not related to cell density, they may still use chemical signals such as AHL for this purpose. AHL production is commonly found in endophytic Pseudomonas spp. than soil-borne Pseudomonas spp. and such strains are more available in plant tissues than in the rhizosphere [177]. It has been reported that signaling compounds secreted by one species could induce density-dependent responses in other species [178]. In S. plymuthica, an endophyte of rice plants, QS was observed to regulate the antifungal activities by affecting the exoenzymes release, though it was unfavorable towards the production of IAA [179]. Azospirillum lipoferum B518, an endophyte of rice plants was able to release AHL signals [180] and thus terminate the pectinase activity, in addition to enhanced synthesis of siderophore and reduction in the production of IAA. However, it has no impact on cellulase activity [181]. Crosstalk among species having a similar AHL signal or framework has been noticed within the root-associated bacteria of wheat and tomato [182]. AHL-mimics impede bacterial QS and regulate the assertion of plant-beneficial activities [183]. 


\subsection{Role of Quorum Sensing in Plant Defense and Biocontrol}

Cellular signal molecules play a key role in regulating plant immune responses and reduce infection by retarding the pathogen proliferation. Bacterial cyclopeptide (CDP), $\mathrm{N}$-acyl-L-homoserine-lactone, AHL produced by QS helps the plant to induce its defense responses. In the case of the ISR of plants, the QS response of bacteria is thought to be of great importance. Endophytic bacteria have been reported to initiate ISR mediating different pathways salicylic acid (SA), Jasmonic acid (JA), and ethylene (ET), which are the signaling pathways involved in ISR induction [184] (Figure 1). Different members of the root endophyte, for example, Pseudomonas, Serratia, Burkholderia [185-187] have been found effective in inducing plant defense with QS response. The role of QS in ISR elicited by Serratia marcescens strain 90-166 in two tobacco plants harboring genes for either AHL degradation (AiiA) or AHL production (AHL) was examined. Root treated with $S$. marcescens strain 90-166 showed increased ISR to the bacterial pathogens (Pectobacterium carotovorum subsp. carotovorum, and Pseudomonas syringae pv. tabaci) in AHL plants and ISR was found to be reduced in AiiA plants. On the other hand, bacterial treatment in AHL plants decreased ISR in the Cucumber mosaic virus, however; it was improved in AiiA plants [188].

The first line of evidence on defense response in plants induced by AHL was demonstrated with AHL producing isolate-Serratia liquefaciens MG1, which could suppress the pathogenicity of Alternaria alternate, the tomato fungal leaf pathogen, more effectively, than compared to the AHL negative mutant [189]. Endophytic Serratia sp. G3 was reported to confer biocontrol activities through AHL-mediated QS molecules. It was found to produce 10 AHLs signal molecules of which the most abundant AHLs detected were 3-oxo-C6HSL (N-hexonoyl-homoserine lactone), C4-HSL (N-butanoyl-homoserine lactone), C6-HSL (N-hexanoyl-homoserine lactone), 3-OH-C6-HSL (N-3-hydroxy-hexanoyl-homoserine lactone), and 3-oxo-C7-HSL (N-3-oxo-heptanoyl-homoserine lactone) [190]. This led to a new phenomenon of AHL-induced resistance. Another remarkable finding showed the rhizobacteria Bacillus pumilus SE3 could cause changes in root cell walls of the plants challenged with Fusarium oxysporum, due to increased callose deposition and phenolic compounds, thereby creating hindrance in fungal infection [191]. A similar study was conducted on Arabidopsis thaliana. The plant treated with exogenous AHL molecules generated a priming response by enhanced deposition of callose, lignin, and phenolic materials upon bacterial infection [192].

\section{Root Colonization and Rhizosphere Competence}

Endophytic colonization involves complex communication between the microbe and the host plant, and usually, it starts by colonizing roots where endophytic microbes require recognition of specific compounds released by the roots [193]. Endophytic bacteria are specialized bacteria that can invade plant roots, and inside the roots they infect adjacent plant tissues [20]. Rhizosphere colonization by PGPR improves plant growth by colonizing the root system and suppresses deleterious rhizosphere microorganisms [194]. PGPR improves the anatomy and plant tissue function present within a particular length from the settled site similar to a shoot; firstly, there is PGPR, which intensifies the intake of nutrients uptake considering the roots of the plant. Alternatively, endophytic plant growth-promoting bacteria trigger plant defense response pathways regulating endophytic colonization. Endophytic colonization by Klebsiella pneumoniae 342 activated the ethylene signaling pathway in Medicago truncatula. An ethylene insensitive mutant of Medicago truncatula was observed to be hypercolonized by Kp342, however, colonization was further found to be reduced with the addition of 1-methylcyclopropene, which is an ethylene function inhibitor. Colonization of Salmonella enterica serovar typhimurium strain 14,028 (that does not harm plant) was observed to be affected by both salicylic acid (SA)-dependent and independent responses. Mutants lacking extracellular components such as flagella or type III secretion system encoded by Salmonella pathogenicity island 1 (TTSS-SPI1) also influenced the endophytic colonization in Medicago spp. in either SA-dependent or SA in- 
dependent responses [195]. Diazotrophic endophytes Gluconacetobacter diazotrophicus PAL5 and Herbaspirillum rubrisulbalbicans HCC103 inoculation in sugarcane exhibited modulation in the expression pattern of a putative ethylene receptor (SCER1) and two putative ERF transcription factors (SCERF1 and SCERF2). The gene expression profile of these factors could establish efficient or inefficient associations with the diazotrophic endophytes, which shoqed a high or low rate of nitrogen fixation, respectively. This revealed SCER1, SCERF1, and SCERF2 contribution in ethylene signaling cascade(s) that could identify endophytic association [196].

Endophytic bacterial colonization in the rhizosphere and their entrance into the endorhiza could progress with the secretion of cell wall degrading enzymes. An endophytic bacterium B. phytofirmans strain PsJN, earlier known as Pseudomonas sp. [197], was later classified as B. phytofirmans PsJN ${ }^{\mathrm{T}}$ [198]. The B. phytofirmans strain PsJN was observed to enter into the endorhiza by secreting endoglucanase and endopolygalacturonase, endo- $\beta$ D-cellobiosidase, and exo- $\beta-1,4$-glucanase. Colonization of peripheral cylinders, mainly xylem vessels and endodermis barrier by the endophytic bacteria, allowed it to spread inside plants [199]. Root endophytes were described to colonize and penetrate the epidermis below the root hair zone and in root cracks [34]. The transport of endophytes from seeds into plant tissues and roots had been demonstrated by endophytes labeled with a green fluorescent protein and their movement was observed to continue throughout the root [200]. The B. phytofirmans strain PsJN migrated from endorhiza to inflorescence organs of grapevine, which would use non-functional vessels, and the strain was detected in the lumen of xylem vessels, which allowed for bacterial progression within plants [199]. Previously it had been assumed that pathogens move through the xylem vessel and endophytes colonized non-functional vessels or transport through the apoplast to reach the aerial parts of the plant [201].

Diazotrophic endophytic bacteria colonize and modify the environment of the host plant through nitrogen fixation. Transcriptomic analysis has indicated the upregulation of nif genes that are involved in nitrogen fixation when bacteria attach to the root surface [202]. Bacteria moving from plant rhizosphere to the endosphere should overcome plant defense responses most importantly through the production of reactive oxygen species (ROS) and reactive nitrogen species (RNS). Endophytic bacteria require detoxification of ROS and RNS to adapt to the environment. The importance of ROS detoxification was observed in Gluconacetobacter diazotrophicus PAL5 during root colonization by superoxide dismutase and glutathione reductase [203].

\section{Endophytic Arbascular Mycorhiza (AMF)}

Arbuscular mycorrhizal fungi and root endophytic fungi are the root symbionts that positively affect plant growth and nutrition [204]. The role of AMF in high phosphorus uptake through activating a specific group of phosphate transporters in plants is well documented [204]. The symbiosis between nitrogen-fixing bacteria (rhizobia and actinorhizas), AMF, and plants affects several functional elements, which includes plant symbiotic signaling pathways, root colonization strategies, the formation of the host-microbe interface, and phytohormone release for root development [205]. Co-inoculation of AMF, Cochliobolus sativus, Diaporthe sp., and Phoma exigua var. exigua exhibited a beneficial effect on biomass yield in Verbascum lychnitis. AMF was found to increase the rate of photosynthesis and abundance of photosystem II core protein (PsbC) revealed an upregulation in plants when the plants were colonized by Epichloe typhina, showing an increase when the negative effect of fungal endophyte was attenuated by AMF [206]. Synergistic interaction of endophytic B. subtilis and AMF showed a significant increase in shoot and root dry weight, nodulation, nutrient acquisition and alleviate the adverse effect of saline stress in Acacia gerrardii [207]. Bacterial diversity and its effect on mycorrhizal symbiosis has been investigated by Deveau et al. [208]. They suggested that bacterial communities in the bulk soil, sporocarps and ectomycorrhizal (EM) root tips of Tuber melanosporum exhibited significant changes in sporocarp formation, while little variation was observed in EMs. AMF represent 
an important niche for interaction with bacteria because the fungi have a large surface area that allows access to photosynthetically derived carbon to the colonizing endophytic bacteria, as observed in Pinus sylvestris [209] and P. muricata [210]. High throughput sequencing elucidated the impact of AMF inoculation on indigenous root microbial communities, which showed inoculation modified the abundance of indigenous AMF and other members of fungi and showed enrichment in several bacterial communities with the introduction of new bacterial species. Members of Microbacterium, Cellulomonas, Burkholderia, Streptomyces, and Sphingomonas were observed to have closely interacted with the introduced AMF while members of Acetobacteraceae, Alicyclobacillaceae, Armatimonadaceae, and Methylobacteriaceae were observed to be reduced with the inoculation [211]. An association of endobacterium Candidatus Glomeribacter gigasporarum with AMF Gigaspora margarita showed a significant increase in fungal primary metabolism and respiration by $50 \%$ [212]. Therefore, the interaction between $\mathrm{AMF}$, endophyte and host plant require attention for its holistic role in the alleviation of stress and plant growth.

\section{Endophytic PGPR and "Omics" Technologies \\ 6.1. Effect of Root-Metabolome on Root-Microbiome}

The microbial populations generate exometabolites, which affect plant growth and other properties. The inoculation of PGP bacteria, including endophytes, has been reported to influence the metabolomic changes in the host plant, which has been described by analyzing the metabolites of root discharge, tissues of root, and shoots. The root enzyme activities including metabolites productivity, mainly flavonoids, can be switched by the action of plant growth-promoting bacteria instigating changes in root discharge pattern [213]. Chryseobacterium balustinum Aur9 was found to regulate flavonoid exudation in soybean roots [214], whereas Chryseobacterium [214] or Azospirillum [215] influenced the discharge of flavonoids in Fabaceae roots. Herbaspirillum seropedicae inoculated rice plants exhibit elevated contents of malate and amino acids in the shoots of the host plant [216]. Bacterial inoculation also influenced the synthesis of various alkaloids and terpenoid compounds [217]. Similarly, when two cultivars of rice were injected with two different strains of Azospirillum, then the metabolic profiles suggested the changes in secondary metabolites, mainly the phenolic compounds [218].

Endophytic fungi Epichloe typhina colonization on plant host Dactylis glomerata endured improvement in photosynthesis efficiency. The abundance of photosystem II proteins LHCI, LHCII, chlorophyll b, and carbon assimilation were revealed to be increased with endophyte colonization. Its colonization increased the malate export out of the chloroplast where assimilated carbon could be transported through malate from chloroplast to apoplast, where endophyte resides, allowing it to sustain better growth of the host plant [219]. Arbuscular mycorrhizal fungi (AMF) enhanced amino acid concentration in the roots of Medicago truncatula [220]. Colonization of Lolium perenne by a fungal endophyte, Neotyphodium lolii decreased the nitrate content and several amino acids of the host plants [221].

Organic acids moderated the bacterial colonization on plant roots and increased the formation of biofilm of the root microbiome. Fumaric acid induced biofilm formation and malic acid induced chemotactic response. Organic acids from rice root exudates contain amino acid residues such as alanine, glycine, histidine, proline, and valine and carbohydrates arabinose, galactose, glucose, glucuronic acid, and mannose induced chemotactic response by endophytic bacteria Corynebacterium flavescens and Bacillus pumillus [222]. Endophytic bacteria Pseudomonas pseudoalcaligenes caused accumulation of higher concentrations of glycine betain-like compounds that assist in the development of tolerance to saline stress in rice [223]. Root endophytic fungus Colletotrichum tofieldia enhanced phosphate translocation in the colonized Arabidopsis plant roots in phosphate deficient conditions. Plant phosphate starvation responses (PSRs) showed regulation of the activities of the fungi. PGP activities of $C$. tofieldia were connected to pathways of the host plant immune system, indicating the active role of the plant through PSRs and the plant immune system while regulating root microbiome under phosphate stress conditions [224]. 


\subsection{Metagenomes of Root-Associated Endophytes}

With recent development in sequencing technologies, endophytic bacteria are now being identified and characterized by culture-independent methods, as only a few of these are culturable [178]. Therefore, culture-independent methods such as metagenomic analysis have been employed for the analysis of plant microbiome composition and functional genes in an environment [225]. The plant-associated endophytic community has a role in protecting the host from biotic and abiotic stress, plant growth promotion, biocontrol, nutrition, and niche adaptation, as revealed by exploring gene expressions, in correlation to genomic and proteomic analyses. Analysis of root-associated microbiome in healthy and nematode infected tomatoes showed nematode infected tomato roots resulted in a reduced abundance of predominant endophytes Streptomycetaceae and Pseudomonadales, which are known to produce active compounds against plant pathogens. Root gall-associated microbiome was found to enrich Flavobacteriales, Sphingobacteriales, and nematode-associated bacteria such as Enterobacteriales and Rhodocyclales [226]. Identification of diverse endophytic communities could lead to an understanding of their interactions, which would assist in managing crop development and health. Characterization of sorghum-associated endophytic bacterial communities showed that root and stem had diverse microbiome, however, both communities were dominated by plant growth-promoting bacterial genera Agrobacterium, Erwinia, Herbaspirillum, Microbacterium, Pseudomonas, Sphingobacterium, and Stenotrophomonas [227]. Inoculation of beneficial microbe caused shifts in the endophytic community structure, which resulted in increased resistance to pathogens in potato, pine, and tomato [228]. Metagenomic analysis of bacterial endophytes in rice roots revealed members of phylum Proteobacteria dominated the endophyte community. Enterobacterrelated endophytes of Gammaproteobacteria and Alphaproteobacteria were found to be abundant. Several gene clusters including protein secretory systems for translocation across cytoplasmic and outer membranes were detected, which could reflect the bacterial community to the endorhizosphere as an exclusive microhabitat. Additionally, endophytic isolates encoded gene components for type VI secretion systems, which are suggestive of beneficial plant-microbe interaction. Rice endophytic microbiome was observed to consist of diverse genes related to hydrolytic plant-polymer-degrading enzymes, detoxification of reactive oxygen species (ROS), glutathione synthases, and glutathione-S-transferases (GST), autoinducer molecules, and iron acquisition [229]. Illumina-based 16 rRNA analysis of bacterial community structure of rhizosphere, phyllosphere, and endosphere of tomato plants showed that bacterial richness decreased from root zone soil to rhizosphere to phyllosphere to endosphere, whereas diversity was decreased from root zone soil to rhizosphere to endosphere to phyllosphere [230]. Proteobacteria was found to be the most abundant phyla associated with tomato plants. At the genus level, endophytes belonging to Acinetobacter, Enterobacter, and Pseudomonas were abundant in roots, leaves, and stems. Root endophytes, which had beneficial effects on plant growth, were more diverse, which was suggested to be due to the interaction between plants and soil [231]. Bacterial community structure depends on the soil type; moreover, organic soils have high moisture retaining capacity as well as organic carbon and nutrients. Endophyte communities in roots were observed to be more diverse in tobacco from organic soils when compared to mineral soils [232]. Under different soil and climatic conditions, the endophytic bacterial community structure of sweet potato was observed to be similar, which indicated that soil and climatic conditions did not affect the endophytic community. The distribution of endophytic genera was found to be dominated by Pseudomonas, followed by Enterobacteriaceae-g, Erwinia, and Burkholderia [233].

Metagenomics and network inference revealed that fungal infection of plant roots increased the members of Chitinophagaceae and Flavobacteriaceae in the root endosphere. This resulted in stimulating enzymatic activities related to fungal cell-wall degradation and enhanced secondary metabolite biosynthetic gene clusters encoded by NRPSs and PKSs. Further, an endophyte identified as Flavobacterium BGC298 genome was observed to encode a metabolite that has antifungal activity or functions such as plant protective 
traits [234]. The genome of endophytic Candidatus Burkholderia kirkii was observed to encode numerous biosynthetic genes for the production of secondary metabolites and protect its host plant Psychotria kirkii. The bacterium was found to produce an antimicrobial compound, C7N aminocyclitol, which showed its importance for the symbiotic association in the leaf nodule [235].

\subsection{Proteome Analysis for the Effect of Endophytes on Host Plants}

The proteomic analysis could identify modifications induced by an endophyte in plant protein expression, such as defense response and hormone production, which could alter plant-endophyte interaction. Metaproteomics determine the functional expression of the microbial community and their metabolic activities using mass spectrophotometry (MS) to characterize protein expression in a given micro-environment [236]. Proteome analysis of Kosakonia radicincitans DSM 16656 inoculated Arabidopsis thaliana revealed 12 protein spots responsive to cellular stress reactions, and inoculation of DSM 16656 increased the expression of $20 \mathrm{~S}$ proteasome alpha-3-subunit. Endophytic colonization was inhibited by the accumulation of ubiquitin-dependent proteins and their degradation and as a result, it showed a decline in proteasome activity, however, inoculation $A$. thaliana mutant (rpn12a) defective in 26S proteasome was found to enhance the plant growth [237]. Inoculation of Sinorhizobium meliloti in rice showed upregulation of plant defense-related proteins in roots and photosynthesis-related proteins in aerial tissues [238]. Similarly, Lery et al. [239], demonstrated differences in the expression of defense response and signaling-related protein, which resulted in different colonization between two sugarcane cultivars with the inoculation of Gluconacetobacter diazotrophicus. The proteomic approach to study plant response towards colonization with endophyte Azoarcus sp. strain BH72 showed that jasmonic acid (JA) could restrict endophytic colonization, indicating that plant defense could control the entry of the endophyte. Rice (Oryza sativa) variety cv. IR42 showed less interaction with the endophyte with JA-induced proteins while other variety $O$. sativa cV. IR36 was colonized by the bacterium induced by JA, which was also induced by the endophyte (SalT, two isoforms). Seven JA-induced proteins were also observed to be induced by the bacterium in cv. IR42 [240]. Fungal endophyte Gilmaniella sp. AL12 inoculation in Atractylodes lancea resulted in a $2.7 \%$ differential gene expression. The upregulated genes were having functional roles in both, primary and secondary metabolism, along with proteins for terpene skeleton biosynthesis. Genes involved in cytokinin biosynthesis and signal transduction were upregulated, which induces cell division and enhanced chlorophyll biosynthesis [241].

\subsection{PGPR Impact on the Plant Transcriptome}

Root inoculation by suitable bacteria, including endophytes, and its effect on different physiological functions of the plant has been described. In Arabidopsis leaves, the overexpression of a total of 520 genes and suppression of a total of 364 genes (threefold changes) was initiated by P. putida MTCC5279 inoculation; upregulated genes were mainly those that have functions similar to genome integrity preservation, repression of ethylene and ABA signaling, and ISR induction and $\mathrm{Ca}^{2+}$ mediated signaling of ISR [242]. Azospirillum brasilense Sp245 inoculation was followed by the expression of ethylene receptors in two cultivars of rice that had the distinct abilities to acquire nitrogen [243]. In another interesting study, the application of endophyte, Azoarcus resulted in the accumulation of transcripts for ethylene receptors in rice plants. Similarly, inoculation with endophytic PGPR Herbaspirillum seropedicae also resulted in altered expression of ethylene, auxin, and defense-linked proteins in rice roots [244]. These indicated that during colonization, the plant defense responses are modulated by endophytes. Inoculation of Pseudomonas fluorescens WCS417r, in Arabidopsis plants, 97 genes within the roots had a different expression, while in leaves, not even a single gene (among 8000 genes) had any significant change in expression level [245]. The transcriptome data also revealed that ISR is induced by P. fluorescens SS101 via salicylic acid signaling in the host plants [246]. In wheat, the accumulation 
of defense-associated transcripts was influenced by the bacterization with $P$. fluorescens Q8r1-96, while the number of transcripts for type three secretion systems and DAPG was not affected [247].

\section{Conclusions}

Root endophytes benefit the host plants directly or indirectly by producing essential phytohormones such as IAA, siderophore, abscisic acid, cytokinin, and solubilize phosphates, which stimulate the growth of the plants. Root endophytes interact with plant roots and assist in nutrient exchange. In addition, the root endophytic microbiomes effectively induce plant defense with quorum sensing response against viral and bacterial pathogens. Advances in emerging technologies such as transcriptomics and metabolomics have provided insights into colonization of the rhizosphere by plant-endophyte and their interaction, which could develop new strategies to improve tolerance to stress. A deeper insight into the role of the root endophytic microbiome for improving plant growth and the physiology of the host plants needs to be explored, along with other factors that shape the specific rhizo-microbiome. This could mark the potential use of endophytes for the benefit of plants and enhance yield. Therefore, it is important to study the diversity of root endophytic microbiomes, their colonization, and their activity for successful application in agricultural lands.

Author Contributions: U.K.V. and J.R. prepared the original manuscript, and J.R. has edited the manuscript. L.P.S. created and described the illustrations. L.S. provided significant inputs for the manuscript structure and contents. H.A., P.D.V.N.S., S.C., R.R., V.S., P.B.M. assisted in literature search, suggestions, and inputs for the content of the manuscript. P.P. envisaged, designed, conceptualized the work, reviewed, wrote, and edited the manuscript. All authors have read and agreed to the published version of the manuscript.

Funding: This research received no external funding.

Institutional Review Board Statement: Not applicable.

Informed Consent Statement: Not applicable.

Data Availability Statement: Not applicable.

Conflicts of Interest: The authors declare no conflict of interest.

\section{References}

1. Van Bavel, J. The world population explosion: Causes, backgrounds and -projections for the future. Facts Views Vis. ObGyn 2013, 5, 281-291. [PubMed]

2. Schoneveld, G.C.; Van der Haara, S.; Ekowati, D.; Andrianto, A.; Komarudin, H.; Okarda, B.; Jelsma, I.; Pacheco, P. Certification, good agricultural practice and smallholder heterogeneity: Differentiated pathways for resolving compliance gaps in the Indonesian oil palm sector. Glob. Environ. Chang. 2019, 57, 101933. [CrossRef]

3. Pervaiz, Z.H.; Iqbal, J.; Zhang, Q.; Chen, D.; Wei, H.; Saleem, M. Continuous Cropping Alters Multiple Biotic and Abiotic Indicators of Soil Health. Soil Syst. 2020, 4, 59. [CrossRef]

4. Özkara, A.; Akyil, D.; Konuk, M. Pesticides, Environmental Pollution, and Health. In Environmental Health Risk-Hazardous Factors to Living Species; InTech: London, UK, 2016.

5. Heinen, R.; Biere, A.; Harvey, J.A.; Bezemer, T.M. Effects of SoilOrganisms on Above ground plant-insect interactions in the field: Patterns, mechanisms and the role of methodology. Front. Ecol. Evol. 2018, 6, 106. [CrossRef]

6. $\quad$ Meena, K.K.; Sorty, A.M.; Bitla, U.M.; Choudhary, K.; Gupta, P.; Pareek, A.; Singh, D.P.; Prabha, R.; Sahu, P.K.; Gupta, V.K.; et al. Abiotic Stress Responses and Microbe-Mediated Mitigation in Plants: The Omics Strategies. Front. Plant Sci. $2017,8,172$. [CrossRef]

7. Glick, B.R. Plant Growth-Promoting Bacteria: Mechanisms and Applications. Scientifica 2012, 2012, 1-15. [CrossRef]

8. Ortíz-Castro, R.; Contreras-Cornejo, H.A.; Macías-Rodríguez, L.; López-Bucio, J. The role of microbial signals in plant growth and development. Plant Signal. Behav. 2009, 4, 701-712. [CrossRef]

9. Chaparro, J.M.; Badri, D.V.; Bakker, M.G.; Sugiyama, A.; Manter, D.K.; Vivanco, J.M. Root exudation of phytochemicals in Arabidopsis follows specific patterns that are developmentally programmed and correlate with soil microbial functions. PLoS ONE 2013, 8, e55731. 
10. Pervaiza, Z.H.; Contreras, J.; Hupp, B.M.; Lindenberger, J.H.; Chen, D.; Zhang, Q.; Wang, C.; Twigg, P.; Saleem, M. Root microbiome changes with root branching order and root chemistry in peach rhizosphere soil. Rhizosphere 2020, 16, 100249. [CrossRef]

11. Compant, S.; Samad, A.; Faist, H.; Sessitsch, A. A review on the plant microbiome: Ecology, functions, and emergingtrends in microbial application. J. Adv. Res. 2019, 19, 29-37. [CrossRef]

12. Richardson, A.E.; Baréa, J.M.; McNeill, A.M.; Prigent-Combaret, C. Acquisition of phosphorus and nitrogen in the rhizosphere and plant growth promotion by microorganisms. Plant Soil. 2009, 321, 305-339. [CrossRef]

13. Couillerot, O.; Prigent-Combaret, C.; Caballero-Mellado, J.; Moënne-Loccoz, Y. Pseudomonas fluorescens and closely-related fluorescent pseudomonads as biocontrol agents of soil-borne phytopathogens. Lett. Appl. Microbiol. 2009, 48, 505-512. [CrossRef] [PubMed]

14. De Souza, R.; Ambrosini, A.; Passaglia, L.M.P. Plant growth-promoting bacteria as inoculants in agricultural soils. Genet Mol. Biol. 2015, 38, 401-419. [CrossRef]

15. Gouda, S.; Kerry, R.G.; Das, G.; Paramithiotis, S.; Shin, H.S.; Patra, J.K. Revitalization of plant growth promoting rhizobacte-ria for sustainable development in agriculture. Microbiol. Res. 2018, 206, 131-140. [CrossRef] [PubMed]

16. Misaghi, I.J.; Donndelinger, C.R. Endophytic bacteria in symptom free cotton plants. Phytopathology 1990, 80, 808-811. [CrossRef]

17. Potshangbam, M.; Devi, S.I.; Sahoo, D.; Strobel, G.A. Functional characterization of endophytic fungal community associated with Oryza sativa L. and Zea mays L. Front. Microbiol. 2017, 8, 325. [CrossRef]

18. Thomas, P.; Sekhar, A.C. Live cell imaging reveals extensive intracellular cytoplasmic colonization of banana by normally non-cultivable endophytic bacteria. AoB Plants 2014, 6, plu002. [CrossRef]

19. Thomas, P.; Reddy, M.K. Microscopic elucidation of abundant endophytic bacteria colonizing the cell wall-plasma membrane peri-space in the shoot-tip tissue of banana. AoB Plants 2013, 5, plt011. [CrossRef]

20. Compant, S.; Clement, C.; Sessitsch, A. Plant growth-promoting bacteria in the rhizo-and endosphere of plants: Their role, colonization, mechanisms involved and prospects for utilization. Soil Biol. Biochem. 2010, 42, 669-678. [CrossRef]

21. Strobel, G. Endophytes as sources of bioactive products. Microbes Infect. 2003, 5, 535-544. [CrossRef]

22. Andreote, F.D.; Lacava, P.T.; Gai, C.S.; Araujo, W.L.; Maccheroni, W.; Overbeek, L.S.V.; Elsas, J.D.V.; Azevedo, J.L. Model plants for studying the interaction between Methylobacterium mesophilicum and Xylella fastidiosa. Can. J. Microbiol. 2006, 52, 419-426. [CrossRef] [PubMed]

23. Xie, H.; Pasternak, J.J.; Glick, B.R. Isolation and characterization of mutants of the plant growth-promoting rhizobacterium Pseudomonas putida GR12-2 that overproduce indoleacetic acid. Curr. Microbiol. 1996, 32, 67-71.

24. James, E.K.; Olivares, F.L. Infection and colonization of sugarcane and other gramineous plants by endophytic diazotrophs. Crit. Rev. Plant Sci. 1998, 17, 77-119. [CrossRef]

25. Verma, S.K.; Kingsley, K.L.; Bergen, M.S.; Kowalski, K.P.; White, J.F. Fungal disease prevention in seedlings of rice (oryza sativa) and other grasses by growth-promoting seed-associated endophytic bacteria from invasive Phragmites australis. Microorganisms 2018, 6, 21. [CrossRef] [PubMed]

26. Paungfoo-Lonhienne, C.; Rentsch, D.; Robatzek, S.; Webb, R.I.; Sagulenko, E.; Nasholm, T.; Schmidt, S.; Lonhienne, T.G.A. Turning the Table: Plants Consume Microbes as a Source of Nutrients. PLoS ONE 2010, 5, e11915. [CrossRef] [PubMed]

27. Thomas, P.; Agrawal, M.; Bharathkumar, C.B. Diverse cellular colonizing endophytic bacteria in field shoots and in vitro cultured papaya with physiological and functional implications. Physiol. Plant. 2019, 166, 729-747. [CrossRef]

28. Lodewyckx, C.; Vangronsveld, J.; Porteous, F.; Moore, E.R.B.; Taghavi, S.; Mergeay, M.; Van der Lelie, D. Endophytic bacteria and their potential applications. Crit. Rev. Plant Sci. 2002, 21, 583-606. [CrossRef]

29. McNear, D.H., Jr. The Rhizosphere-Roots, soil and everything in between. Nat. Educ. 2013, 4, 1.

30. Rosier, A.; Medeiros, F.H.V.; Bais, H.P. Defining plant growth promoting rhizobacteria molecular and biochemical networks in beneficial plant-microbe interactions. Plant Soil 2018, 428, 35-55. [CrossRef]

31. Oliveira, A.L.M.; Urquiaga, S.; Baldani, J.I. Processos e Mecanismos Envolvidos na Influência de Microrganismos Sobre o Crescimento Vegetal. Seropédica: CNPAB, Ago; Embrapa Agrobiologia-Documentos 161; Embrapa: Brasilia, Brazil, 2003 ; p. 40.

32. Xia, Y.; DeBolt, S.; Dreyer, J.; Scott, D.; Williams, M.A. Characterization of culturable bacterial endophytes and their capacity to promote plant growth from plants grown using organic or conventional practices. Front. Plant Sci. 2015, 6, 490. [CrossRef]

33. Hallmann, J.; Quadt-Hallmann, A.; Mahaffee, W.F.; Kloepper, J.W. Bacterial endophytes in agricultural crops. Can. J. Microbiol. 1997, 43, 895-914. [CrossRef]

34. Zakria, M.J.; Njolom, A.; Saeki, Y.; Akao, S. Colonization and nitrogen-fi xing ability of Herbaspirillum sp. strain B501 gfp1 and assessment of its growth-promoting ability in cultivated rice. Microbes Environ. 2007, 22, 197-206. [CrossRef]

35. Costa, F.E.C.; Melo, I.S. Endophytic and rhizospheric bacteria from Opuntia ficus-indica mill and their ability to promote plant growth in cowpea, Vigna unguiculata (L.) Walp. Afr. J. Microbiol. Res. 2012, 6, 1345-1353.

36. Olanrewaju, O.S.; Ayangbenro, A.S.; Glick, B.R.; Babalola, O.O. Plant health: Feedback effect of root exudates-rhizobiome interactions. Appl. Microbiol. Biotechnol. 2019, 103, 1155-1166. [CrossRef] [PubMed]

37. Canarini, A.; Kaiser, C.; Merchant, A.; Richter, A.; Wanek, W. Root Exudation of Primary Metabolites: Mechanisms and Their Roles in Plant Responses to Environmental Stimuli. Front. Plant Sci. 2019, 10, 157. [PubMed]

38. Pii, Y.; Mimmo, T.; Tomasi, N.; Terzano, R.; Cesco, S.; Crecchio, C. Microbial interactions in the rhizosphere: Beneficial influencesof plant growth-promoting rhizobacteria on nutrient acquisitionprocess. A review. Biol. Fertil. Soils 2015, 51, 403-415. [CrossRef] 
39. Ahemad, M.; Kibret, M. Mechanisms and applications of plant growth-promoting rhizobacteria: Current perspective. J. King Saud. Univ. Sci. 2014, 26, 1-20. [CrossRef]

40. Li, Z.; Zu, C.; Wang, C.; Yang, J.; Yu, H.; Wu, H. Different responses of rhizosphere and non-rhizosphere soil microbial communities to consecutive Piper nigrum L. monoculture. Sci. Rep. 2016, 6, 35825. [CrossRef] [PubMed]

41. Kloepper, J.W.; Schroth, M.N. Plant growth-promoting rhizobacteria on radishes. In Proceedings of the 4th International Conf. on Plant Pathogenic Bacteria, Station de Pathologie Vegetable et Phytobacteriologie, INRA, Angers, France, 27 August-2 September 1978; pp. 879-882.

42. Verma, J.P.; Yadav, J.; Tiwari, K.N.; Lavakush; Singh, V. Impact of Plant Growth Promoting Rhizobacteria on Crop Production. Int. J. Agric. Res. 2010, 5, 954-983. [CrossRef]

43. Antoun, H.; Kloepper, J. Plant Growth Promoting Rhizobacteria (PGPR). Encycl. Genet. 2001, 1, 1477-1480.

44. Barea, J.M. Future challenges and perspectives for applying microbial biotechnology in sustainable agriculture based on a better understanding of plant-microbiome interactions. J. Soil Sci. Plant Nutr. 2015, 15, 261-282. [CrossRef]

45. Olanrewaju, O.S.; Glick, B.R.; Babalola, O.O. Mechanisms of action of plant growth promoting bacteria. World J. Microbiol. Biotechnol. 2017, 33, 1-16. [CrossRef]

46. Khan, M.S.; Gao, J.; Chen, X.; Zhang, M.; Yang, F.; Du, Y.; Moe, T.S.; Munir, I.; Xue, J.; Zhang, X. Isolation and characterization of plant growth-promoting endophytic bacteria Paenibacillus polymyxa SK1 from Lilium lancifolium. BioMed Res. Int. 2020, 2020, 8650957. [CrossRef] [PubMed]

47. Ferchichi, N.; Toukabri, W.; Boularess, M.; Smaoui, A.; Mhamdi, R.; Trabelsi, D. Isolation, identification and plant growth promotion ability of endophytic bacteria associated with lupine root nodule grown in Tunisian soil. Arch. Microbiol. 2019, 201, 1333-1349. [CrossRef]

48. Maggini, V.; Mengoni, A.; Gallo, E.R.; Biffi, S.; Fani, R.; Firenzuoli, F.; Bogani, P. Tissue specificity and differential effects on in vitro plant growth of single bacterial endophytes isolated from the roots, leaves and rhizospheric soil of Echinacea purpurea. BMC Plant Biol. 2019, 19, 1-9. [CrossRef]

49. Borah, A.; Das, R.; Mazumdar, R.; Thakur, D. Culturable endophytic bacteria of Camellia species endowed with plant growth promoting characteristics. J. Appl. Microbiol. 2019, 127, 1364-5072. [CrossRef] [PubMed]

50. Abedinzadeh, M.; Etesami, H.; Alikhani, H.A. Characterization of rhizosphere and endophytic bacteria from roots of maize (Zea mays L.) plant irrigated with wastewater with biotechnological potential in agriculture. Biotechnol. Rep. 2018, 20, e00305. [CrossRef]

51. Chen, X.; Pizzatti, C.; Bonaldi, M.; Saracchi, M.; Erlacher, A.; Kunova, A.; Berg, G.; Cortesi, P. Biological Control of Lettuce Drop and Host Plant Colonization by Rhizospheric and Endophytic Streptomycetes. Front. Microbiol. 2016, 7, 714. [CrossRef]

52. Egamberdieva, D.; Jabborova, D.; Berg, G. Synergistic interactions between Bradyrhizobium japonicum and the endophyte Stenotrophomonas rhizophila and their effects on growth, and nodulation of soybean under salt stress. Plant Soil 2015, 405, 35-45. [CrossRef]

53. Upadhyay, S.K.; Singh, J.S.; Saxena, A.K.; Singh, D.P. Impact of PGPR inoculation on growth and antioxidant status of wheat under saline conditions. Plant Biol. 2012, 4, 605-611. [CrossRef]

54. Shi, Y.; Lou, K.; Li, C. Growth and photosynthetic efficiency promotion of sugar beet (Beta vulgaris L.) by endophytic bacteria. Photosynth. Res. 2010, 105, 5-13. [CrossRef] [PubMed]

55. Weilharter, A.; Mitter, B.; Shin, M.V.; Chain, P.S.; Nowak, J.; Sessitsch, A. Complete genome sequence of the plant growthpromoting endophyte Burkholderia phytofirmans strain PsJN. J. Bacteriol. 2011, 193, 3383-3384. [CrossRef] [PubMed]

56. De Torres-Zabala, M.; Bennett, M.H.; Mansfield, J.W.; Egea, R.; Bo, L.; Grant, M. Pseudomonas syringae pv. tomato hijacks the Arabidopsis abscisic acid signalling pathway to cause disease. EMBO J. 2007, 26, 1434-1443. [CrossRef]

57. Cocking, E.C. Endophytic colonization of plant roots by nitrogen-fixing bacteria. Plant Soil 2003, 252, 169-175. [CrossRef]

58. Yanni, Y.G.; Rizk, R.Y.; Abd El-Fattah, F.K.; Squartini, A.; Corich, V.; Giacomini, A.; De Bruijn, F.; Rademaker, J.; Maya-Flores, J.; Ostrom, P.; et al. The beneficial plant growth promoting association of Rhizobium leguminosarum bv. trifolii with rice roots. Aust. J. Plant Physiol. 2001, 28, 845-870. [CrossRef]

59. Santoyo, G.; Moreno-Hagelsieb, G.; Orozco-Mosqueda, M.C.; Glick, B.R. Plant growth-promoting bacterial endophytes. Microbiol. Res. 2016, 183, 92-99. [CrossRef]

60. Bekri, M.A.; Desair, J.; Keijers, V.; Proost, P.; Searle-van Leeuwen, M.; Vanderleyden, J.; vande Broek, A. Azospirillum irakense produces a novel type of pectate lyase. J. Bacteriol. 1999, 181, 2440-2447. [CrossRef]

61. Sekar, C.; Prasad, N.N.; Sundaram, M.D. Enhancement of polygalacturonase activity during auxin induced para nodulation and endorhizosphere colonization of Azospirillum in rice roots. J. Exp. Biol. 2000, 38, 80-83.

62. Agbodjato, N.A.; Noumavo, P.A.; Baba-Moussa, F.; Salami, H.A.; Sina, H.; Sèzan, A.; Bankolé, H.; Adjanohoun, A.; Baba-Moussa, L. Characterization of Potential Plant Growth Promoting Rhizobacteria Isolated from Maize (Zea mays L.) in Central and Northern Benin (West Africa). Appl. Environ. Soil Sci. 2015, 2015, 1-9. [CrossRef]

63. Bruto, M.; Prigent-Combaret, C.; Muller, D.; Moënne-Loccoz, Y. Analysis of genes contributing to plant-beneficial functions in plant growth-promoting rhizobacteria and related Proteobacteria. Sci. Rep. 2014, 4, srep06261. [CrossRef]

64. Lei, X.; Wang, E.T.; Chen, W.F.; Sui, X.H.; Chen, W.X. Diverse bacteria isolated from root nodules of wild Vicia species grown in temperate region of China. Arch. Microbiol. 2008, 190, 657-671. [CrossRef] [PubMed] 
65. Wang, D.; Yang, S.; Tang, F.; Zhu, H. Symbiosis specificity in the legume: Rhizobial mutualism. Cell. Microbiol. 2012, 14, 334-342. [CrossRef] [PubMed]

66. Muthukumarasamy, R.; Cleenwerck, I.; Revathi, G.; Vadivelu, M.; Janssens, D.; Hoste, B.; Caballero-Mellado, J. Natural association of Gluconacetobacter diazotrophicus and diazotrophic Acetobacter peroxydans with wetland rice. Syst. Appl. Microbiol. 2005, 28, 277-286. [CrossRef] [PubMed]

67. Hurek, T.; Reinhold-Hurek, B. Azoarcus sp. strain BH72 as a model for nitrogen fixing grass endophytes. J. Biotechnol. 2003, 106, 169-178. [CrossRef]

68. Engelhard, M.; Hurek, T.; Reinhold-Hurek, B. Preferential occurrence of diazotrophic endophytes, Azoarcus spp., in wild rice species and land races of Oryza sativa in comparison with modern races. Environ. Microbiol. 2000, 2, 131-141. [CrossRef] [PubMed]

69. Masson-Boivin, C.; Sachs, J.L. Symbiotic nitrogen fixation by rhizobia-The roots of a success story. Curr. Opin. Plant Biol. 2018, 44, 7-15. [CrossRef]

70. Lindstrom, K.; Mousavi, S.A. Effectiveness of nitrogen fixation in rhizobia. Microb. Biotechnol. 2020, 13, 1314-1335. [CrossRef]

71. Robledo, M.; Garcia-Tomsig, N.I.; Jimenez-Zurdo, J.I. Riboregulation in Nitrogen-Fixing Endosymbiotic Bacteria. Microorganisms 2020, 8, 384. [CrossRef]

72. Sharma, S.B.; Sayyed, R.Z.; Trivedi, M.H.; Gobi, T.A. Phosphate solubilizing microbes: Sustainable approach for managing phosphorus deficiency in agricultural soils. Springerplus 2013, 2, 1-14. [CrossRef]

73. Khan, M.S.; Zaidi, A.; Wani, P.A. Role of phosphate-solubilizing microorganisms in sustainable agriculture-A review. Agron. Sustain. Dev. 2007, 27, 29-43. [CrossRef]

74. Bhattacharyya, P.N.; Jha, D.K. Plant growth-promoting rhizobacteria (PGPR): Emergence in agriculture. World J. Microbiol. Biotechnol. 2012, 28, 1327-1350. [CrossRef] [PubMed]

75. Kpomblekou-A, K.; Tabatabai, M.A. Effect of low-molecular weight organic acids on phosphorus release and phytoavailabilty of phosphorus in phosphate rocks added to soils. Agric. Ecosyst. Environ. 2003, 100, 275-284. [CrossRef]

76. Forchetti, G.; Masciarelli, O.; Alemano, S.; Alvarez, D.; Abdala, G. Endophytic bacteria in sunfl ower (Helianthus annuus L.): Isolation, characterization, and production of jasmonates and abscisic acid in culture medium. Appl. Microbiol. Biotechnol. 2007, 76, 1145-1152. [CrossRef] [PubMed]

77. Kuklinsky-Sobral, W.L.; Araujo, R.; Mendes, I.O.; Geraldi, A.A.; Pizzirani-Kleiner, J.L. Isolation and characterization of soybeanassociated bacteria and their potential for plant growth promotion. Environ. Microbiol. 2004, 6, 1244-1251. [CrossRef]

78. Oteino, N.; Lally, R.D.; Kiwanuka, S.; Lloyd, A.; Ryan, D.; Germaine, K.J.; Dowling, D.N. Plant growth promotion induced by phosphate solubilizing endophytic Pseudomonas isolates. Front. Microbiol. 2015, 6, 745. [CrossRef]

79. Spaepen, S.; Vanderleyden, J.; Remans, R. Indole-3-acetic acid in microbial and microorganism-plant signaling. FEMS Microbiol. Rev. 2007, 31, 425-448. [CrossRef]

80. Spaepen, S.W.; Gocke, D.; Pohl, M.; Steyaert, J.; Vanderleyden, J. Characterization of phenylpyruvate decarboxylase, involved in auxin production of Azospirillum brasilense. J. Bacteriol. 2007, 189, 7626-7633. [CrossRef]

81. Remans, R.; Beebe, S.; Blair, M.; Manrique, G.; Tovar, E.; Rao, I.; Croonenborghs, A.; Torres-Gutierrez, R.; El-Howeity, M.; Michiels, J.; et al. Physiological and genetic analysis of root responsiveness to auxin-producing plant growth-promoting bacteria in common bean (Phaseolus vulgaris L.). Plant Soil 2008, 302, 149-161. [CrossRef]

82. Ji, S.H.; Gururani, M.A.; Chun, S.-C. Isolation and characterization of plant growth promoting endophytic diazotrophicbacteria from Korean rice cultivars. Microbiol. Res. 2014, 169, 83-98. [CrossRef]

83. Spaepen, S.; Vanderleyden, J. Auxin and plant-microbe interactions. Cold Spring Harb. Perspect. Biol. 2011, 3, a001438. [CrossRef]

84. Jasim, B.; Jimtha, J.C.; Shimil, V.; Jyothis, M.; Radhakrishnan, E.K. Studies on the factors modulating indole-3-acetic acid production in endophytic bacterial isolates from Piper nigrum and molecular analysis of ipdc gene. J. Appl. Microbiol. 2014, 117, 786-799. [CrossRef] [PubMed]

85. Defez, R.; Esposito, R.; Angelini, A.; Bianco, C. Overproduction of indole-3-acetic acid in free-living rhizobia induces transcriptional changes resembling those occurring inside nodule bacteroids. Mol. Plant Microbe Interact. 2016, 29, 484-495. [CrossRef] [PubMed]

86. Defez, R.; Andreozzi, A.; Bianco, C. The overproduction of indole-3-acetic acid (IAA) in endophytes upregulates nitrogen fixation in both bacterial cultures and inoculated rice plants. Microb. Ecol. 2017, 74, 441-452. [CrossRef] [PubMed]

87. Zhu, X.F.; Wang, Z.W.; Dong, F.; Lei, G.J.; Shi, Y.Z.; Li, G.X.; Zheng, S.J. Exogenous auxin alleviates cadmium toxicity in Arabidopsis thaliana by stimulating synthesis of hemicellulose 1 and increasing the cadmium fixation capacity of root cell walls. J. Hazard. Mater. 2013, 263, 398-403. [CrossRef]

88. Bhutani, N.; Maheshwari, R.; Negi, M.; Suneja, P. Optimization of IAA production by endophytic Bacillus spp. from Vigna radiatafor their potential use as plant growth promoters. Isr. J. Plant Sci. 2018, 65, 1-2. [CrossRef]

89. Tsavkelova, E.A.; Cherdyntseva, T.A.; Botina, S.G.; Netrusov, A.I. Bacteria associated with orchid roots and microbial production of auxin. Microbiol. Res. 2007, 162, 69-76. [CrossRef]

90. Chandra, S.; Askari, K.; Kumari, M. Optimization of indole acetic acid production by isolated bacteria from Stevia rebaudiana rhizosphere and its effects on plant growth. J. Genet. Eng. Biotechnol. 2018, 16, 581-586. [CrossRef]

91. Ali, B.; Hasnain, S. Potential of bacterial indoleacetic acid to induce adventitious shoots in plant tissue culture. Lett. Appl. Microbiol. 2007, 45, 128-133. [CrossRef] 
92. Luo, S.; Xu, T.; Chen, L.; Chen, J.; Ra, C.; Xiao, X.; Wan, Y.; Zeng, G.; Long, F.; Liu, C.; et al. Endophyte-assisted promotion of biomass production and metal-uptake of energy crop sweet sorghum by plant-growth-promoting endophyte Bacillus sp. SLS18. Appl. Microbiol. Biotechnol. 2012, 93, 1745-1753.

93. Verma, V.C.; Singh, S.K.; Prakash, S. Bio-control and plant growth promotion potential of siderophore producing endophytic Streptomyces from Azadirachta indica A. Juss. J. Basic Microbiol. 2011, 51, 550-556. [CrossRef]

94. Walitang, D.I.; Kim, K.; Madhaiyan, M.; Kim, Y.K.; Kang, Y.; Sa, T. Characterizing endophytic competence and plant growth promotion of bacterial endophytes inhabiting the seed endosphere of Rice. BMC Microbiol. 2017, 17, 209. [CrossRef] [PubMed]

95. Khan, A.L.; Waqas, M.; Kang, S.-M.; Al-Harrasi, A.; Hussain, J.; Al-Rawahi, A.; Al-Khiziri, S.; Ullah, I.; Ali, L.; Jung, H.-Y.; et al. Bacterial Endophyte Sphingomonas sp. LK11 produces gibberellins and IAA and promotes tomato plant growth. J. Microbiol. 2014, 52, 689-695. [CrossRef] [PubMed]

96. Iqbal, N.; Khan, N.A.; Ferrante, A.; Trivellini, A.; Francini, A.; Khan, M.I.R. Ethylene role in plant growth, development and senescence: Interaction with other phytohormones. Front. Plant Sci. 2017, 8, 475. [CrossRef] [PubMed]

97. Glick, B.R.; Cheng, Z.; Czarny, J.; Duan, J. Promotion of plant growth by ACC deaminase-producing soil bacteria. Eur. J. Plant Pathol. 2007, 119, 329-339. [CrossRef]

98. Gupta, S.; Pandey, S. ACC deaminase producing bacteria with multifarious plant growth promoting traits alleviates salinity stress in French Bean (Phaseolus vulgaris) plants. Front Microbiol. 2019, 10, 1506. [CrossRef]

99. Nonaka, S.; Sugawara, M.; Minamisawa, K.; Yuhashi, K.I.; Ezura, H. 1-aminocyclopropane-1-carboxylate deaminase producing Agrobacterium confers higher ability for gene transfer into plant cells. Appl. Environ. Microbiol. 2008, 74, 2526-2528. [CrossRef]

100. Jasim, B.; Jimtha, C.J.; Jyothis, M.; Radhakrishnan, E.K. Plant growth promoting potential of endophytic bacteria isolated from Piper nigrum. Plant Growth Regul. 2013, 71, 1-11. [CrossRef]

101. Thanananta, T. Cloning of 1-Aminocyclopropane-1- carboxylate Deaminase Gene from Soil Microorganism. Int. J. Sci. Technol. $1997,2,56-60$.

102. Zamioudis, C.; Mastranesti, P.; Dhonukshe, P.; Blilou, I.; Pieterse, C.M. Unraveling root developmental programs initiated by beneficial Pseudomonas spp. bacteria. Plant Physiol. 2013, 162, 304-318. [CrossRef]

103. Rashid, S.; Charles, T.C.; Glick, B.R. Isolation and characterization of new plant growth-promoting bacterial endophytes. Appl. Soil Ecol. 2012, 61, 217-224. [CrossRef]

104. Scheres, B.; Benfey, P.; Dolan, L. Root Development. Arab. Book. 2002, 1, e0101. [CrossRef] [PubMed]

105. Lauter, F.R.; Ninnemann, O.; Bucher, M.; Riesmeier, J.W.; Frommer, W.B. Preferential expression of an ammonium transporter and of two putative nitrate transporters in root hairs of tomato. Proc. Natl. Acad. Sci. USA 1996, 93, 8139-8144. [CrossRef] [PubMed]

106. Vacheron, J.; Desbrosses, G.; Bouffaud, M.-L.; Touraine, B.; Moënne-Loccoz, Y.; Muller, D.; Legendre, L.; Wisniewski-Dyé, F.; Prigent-Combaret, C. Plant growth-promoting rhizobacteria and root system functioning. Front Plant Sci. 2013, 4, 356. [CrossRef] [PubMed]

107. Ahn, S.J.; Shin, R.; Schachtma, D.P. Expression ofKT/KUPgenes in Arabidopsis and the role of root hairs in $\mathrm{K}^{+}$uptake. Plant Physiol. 2004, 134, 1135-1145. [CrossRef] [PubMed]

108. Pothier, J.F.; Wisniewski-Dyé, F.; Weiss-Gayet, M.; Mënne-Loccoz, Y.; Prigent-Combaret, C. Promoter-trap identification of wheat seed extract-induced genes in the plant-growth-promoting rhizobacterium Azospirillum brasilense Sp245. Microbiology 2007, 153, 3608-3622. [CrossRef]

109. Niranjan-Raj, S.; Lavanya, S.; Amruthesh, K.; Niranjana, S.; Shetty, H.S. Comparative evaluation of Pseudomonas fluorescens and their lipopolysaccharides as implicated in induction of resistance against pearl millet downy mildew. Arch. Phytopathol. Plant Prot. 2011, 44, 1285-1299. [CrossRef]

110. Ryu, C.M.; Farag, M.A.; Hu, C.-H.; Reddy, M.S.; Wei, H.-X.; Pare, P.W.; Kloepper, J.W. Bacterial volatiles promote growth in Arabidopsis. Proc. Natl. Acad. Sci. USA 2003, 100, 4927-4932. [CrossRef]

111. Dodd, I.C.; Zinovkina, N.Y.; Safronova, V.I.; Belimov, A.A. Rhizobacterial mediation of plant hormone status. Ann. Appl. Biol. 2010, 157, 361-379. [CrossRef]

112. Aloni, R.; Aloni, E.; Langhans, M.; Ullrich, C.I. Role of cytokinin and auxin in shaping root architecture: Regulating vascular differentiation, lateral root initiation, root apical dominance and root gravitropism. Ann. Bot. 2006, 97, 883-893. [CrossRef]

113. Bakker, P.A.; Pieterse, C.M.; Van Loon, L.C. Induced systemic resistance by fluorescent Pseudomonas spp. Phytopathology 2007, 97, 239-243. [CrossRef]

114. Phillips, D.A.; Fox, T.C.; King, M.D.; Bhuvaneswari, T.V.; Teuber, L.R. Microbial products trigger amino acid exudation from plant roots. Plant Physiol. 2004, 136, 2887-2894. [CrossRef]

115. Contesto, C.; Milesi, S.; Mantelin, S.; Zancarini, A.; Desbrosses, G.; Varoquaux, F.; Bellini, C.; Kowalczyk, M.; Touraine, B. The auxin-signaling pathway is required for the lateral root response of Arabidopsis to the rhizobacterium Phyllobacterium brassicacearum. Planta 2010, 232, 1455-1470.

116. Cacciari, I.; Lippi, D.; Pietrosanti, T.; Pietrosanti, W. Phytohormone-like substances produced by single and mixed diazotrophic cultures of Azospirillum and Arthrobacter. Plant Soil 1989, 115, 151-153. [CrossRef]

117. Hussain, A.; Hasnain, S. Cytokinin production by some bacteria: Its impact on cell division in cucumber cotyledons. Afr. J. Microbiol. Res. 2009, 3, 704-712.

118. Ahmed, E.; Holmström, S.J.M. Siderophores in environmental research: Roles and applications. Microb. Biotechnol. 2014, 7, 196-208. [CrossRef] 
119. Wilson, M.K.; Abergel, R.J.; Arceneaux, J.E.; Raymond, K.N.; Byers, B.R. Temporal production of the two Bacillus anthracis siderophores, petrobactin and bacillibactin. Biometals 2010, 23, 129-134. [CrossRef]

120. Ferreira, M.J.; Silva, H.; Cunha, A. Siderophore-producing rhizobacteria as a promising tool for empowering plants to cope with iron limitation in saline soils: A review. Pedosphere 2019, 29, 409-420. [CrossRef]

121. Pérez-Montaño, F.; Alías-Villegas, C.; Bellogín, R.A.; del Cerro, P.; Espuny, M.R.; Jimenez-Guerrero, I.; Lopez-Baena, F.J.; Ollero, F.J.; Cubo, T. Plant growth promotion in cereal and leguminous agricultural important plants: From microorganism capacities to crop production. Microbiol. Res. 2014, 169, 325-336. [CrossRef]

122. Burd, G.I.; Dixon, D.G.; Glick, B.R. Plant growth-promoting bacteria that decrease heavy metal toxicity in plants. Can. J. Microbiol. 2000, 46, 237-245. [CrossRef]

123. Rajkumar, M.; Ae, N.; Prasad, M.N.V.; Freitas, H. Potential of siderophore-producing bacteria for improving heavy metal phytoextraction. Trends Biotechnol. 2010, 28, 142-149. [CrossRef]

124. Idris, R.; Trifonova, R.; Puschenreiter, M.; Wenzel, W.W.; Sessitsch, A. Bacterial communities associated with flowering plants of the Ni hyperaccumulator Thlaspi goesingense. Appl. Environ. Microb. 2004, 70, 2667-2677. [CrossRef]

125. Sheng, X.F.; Xia, J.J.; Jiang, C.Y.; He, L.Y.; Qian, M. Characterization of heavy metal-resistant endophytic bacteria from rape (Brassica napus) roots and their potential in promoting the growth and lead accumulation of rape. Environ. Pollut. 2008, 156, 1164-1170. [CrossRef]

126. Schalk, I.J. Metal trafficking via siderophores in Gram negative bacteria: Specificities and characteristics of the pyoverdine pathway. J. Inorg. Biochem. 2008, 102, 1159-1169. [CrossRef]

127. El-Tarabily, K.A.; Nassar, A.H.; Hardy, G.E.S.J.; Sivasithamparam, K. Plant growth promotion and biological control of Pythium aphanidermatum, a pathogen of cucumber, by endophytic actinomycetes. J. Appl. Microbiol. 2009, 106, 13-26. [CrossRef]

128. Franco, C.M.M.; Michelsen, P.; Conn, V.M.; Loria, R.; Moll, S. Endophytic actinomycetes: Effective biocontrolagents for cereal root diseases. Phytopathology 2006, 96, S37.

129. Kloepper, J.W.; Leong, J.; Teintze, M.; Schroth, M.N. Pseudomonas siderophores: A mechanism explaining disease-suppressive soils. Curr. Microbiol. 1980, 4, 317-320. [CrossRef]

130. Li, J.H.; Wang, E.T.; Chen, W.F.; Chen, W.X. Genetic diversity and potential for promotion of plant growth detected in nodule endophytic bacteria of soybean grown in Heilongjiang province of China. Soil Biol. Biochem. 2008, 40, 238-246. [CrossRef]

131. Budzikiewicz, H. Secondary metabolites from fluorescent Pseudomonas. FEMS Microbiol. Rev. 1993, 104, 209-228. [CrossRef]

132. Ryan, R.P.; Monchy, S.; Cardinale, M.; Taghavi, S.; Crossman, L.; Avison, M.B.; Berg, G.; Van der Lelie, D.; Dow, J.M. The versatility and adaptation of bacteria from the genus Stenotrophomonas. Nat. Rev. Microbiol. 2009, 7, 514-525. [CrossRef]

133. Rijavec, T.; Lapanje, A. Hydrogen cyanide in the rhizosphere: Not suppressing plant pathogens, but rather regulating availability of phosphate. Front Microbiol. 2016, 7, 1785. [CrossRef]

134. Prasad, M.P.; Dagar, S. Identification and characterization of endophytic bacteria from fruits like avocado and black grapes. Int. J. Curr. Microbiol. Appl. Sci. 2014, 3, 937-947.

135. Rudrappa, T.; Splaine, R.E.; Biedrzycki, M.L.; Bais, H.P. Cyanogenic pseudomonads influence multitrophic interactions in the rhizosphere. PLoS ONE 2008, 3, e2073. [CrossRef]

136. Pal, K.K.; Gardener, B.M. Biological control of plant pathogens. Plant Health Instr. 2006, 1-25. [CrossRef]

137. Sakiyama, C.C.H.; Paula, E.M.; Pereira, P.C.; Borges, A.C.; Silva, D.O. Characterization of pectin lyase producedby an endophytic strain isolated from coffee cherries. Lett. Appl. Microbiol. 2001, 33, 117-121. [CrossRef]

138. Tripathi, S.; Kamal, S.; Sheramati, I.; Oelmuller, R.; Varma, A. Mycorrhizal Fungi and other Root Endophytes as Biocontrol Agents Against Root Pathogens, in Mycorrhiza; Varma, A., Ed.; Springer: Berlin/Heidelberg, Germany, 2008; pp. 281-306.

139. Jadhav, H.P.; Shaikh, S.S.; Sayyed, R.Z. Role of hydrolytic enzymes of rhizoflora in biocontrol of fungal phytopathogens: An overview. In Rhizotrophs: Plant Growth Promotion to Bioremediation; Springer: Singapore, 2017; pp. 183-203.

140. Badreddine, I.; Lafitte, C.; Heux, L.; Skandalis, N.; Spanou, Z.; Martinez, Y.; Esquerre-Tugaye, M.-T.; Bulone, V.; Dumas, B.; Bottin, A. Cell wall chitosaccharides are essential components and exposed patterns of the phytopathogenic oomycete Aphanomyces euteiches. Eukaryot. Cell 2008, 7, 1980-1993. [CrossRef]

141. Khare, E.; Yadav, A. The Role of Microbial Enzyme Systems in Plant Growth Promotion. Clim. Chang. Environ. Sustain. 2017, 5, 122. [CrossRef]

142. Jadhav, H.P.; Sayyed, R.Z. Hydrolytic Enzymes of Rhizospheric Microbes in Crop Protection. MOJ Cell Sci. Rep. 2016, 3, 135-136.

143. Mercado-Blanco, J.; Bakker, P.A.H.M. Interactions between plantsand beneficial Pseudomonas spp.: Exploiting bacterial traits for crop protection. Antonie Leeuwenhoek 2007, 92, 367-389. [CrossRef]

144. Ryan, R.P.; Germaine, K.; Franks, A.; Ryan, D.J.; Dowling, D.N. Bacterial endophytes: Recent developments and applications. FEMS Microbiol. Lett. 2008, 278, 1-9. [CrossRef]

145. Someya, N.; Kataoka, N.; Komagata, T.; Hirayae, K.; Hibi, T.; Akutsu, K. Biological control of cyclamen soil borne diseases by Serratia marcescens strain B2. Plant Dis. 2000, 84, 334-340. [CrossRef]

146. Fridlender, M.; Inbar, J.; Chet, I. Biological control of soil borne plant pathogens by a B-1,3-glucanase producing Pseudomonas cepacia. Soil Biol. Biochem. 1993, 25, 1211-1221. [CrossRef]

147. Budi, S.W.; Van Tuinen, D.; Arnould, C.; Dumas-Gaudot, E.; Gianinazzi-Pearson, V.; Gianinazzi, S. Hydrolytic enzyme activity of Paenibacillus sp. strain B2 and effects of the antagonistic bacterium on cell integrity of two soil borne pathogenic fungi. Appl. Soil Ecol. 2000, 15, 191-199. [CrossRef] 
148. Garbeva, P.; Van Veen, J.A.; Van Elas, J.D. Assessment of the diversity, and antagonism towards Rhizoctonia solani AG3, of Pseudomonas species in soil from different agricultural regimes. FEMS Microbiol. Ecol. 2004, 47, 51-64.

149. Loqman, S.; Ait Barka, E.; Clément, C.; Ouhdouch, Y. Antagonistic actinomycetes from Moroccan soil to control the grapevine gray mold. World J. Microbiol. Biotechnol. 2009, 25, 81-91. [CrossRef]

150. Palumbo, J.D.; Yuen, G.Y.; Jochum, C.C.; Tatum, K.; Kobayashi, D.Y. Mutagenesis of beta-1,3-Glucanase Genes in Lysobacter enzymogenes Strain C3 Results in Reduced Biological Control Activity Toward Bipolaris Leaf Spot of Tall Fescue and Pythium Damping-Off of Sugar Beet. Phytopathology 2005, 95, 701-707. [CrossRef]

151. Macagnan, D.; Romeiro, R.S.; Pomella, A.W.V.; De Souza, J.T. Production of lytic enzymes and siderophores, and inhibition of germination of basidiospores of Moniliophthora (ex Crinipellis) perniciosaby phylloplane actinomycetes. Biol. Control 2008, 47, 309-314. [CrossRef]

152. Verma, S.C.; Ladha, J.K.; Tripathi, A.K. Evaluation ofplant growth promoting and colonization abilityof endophyti cdiazotrophs from deep water rice. J. Biotechnol. 2001, 91, 127-141. [CrossRef]

153. Vurukonda, S.S.K.P.; Giovanardi, D.; Stefani, E. Plant Growth Promoting and Biocontrol Activity of Streptomyces spp. as Endophytes. Int. J. Mol. Sci. 2018, 19, 952. [CrossRef]

154. El-Banna, N.; Winkelmann, G. Pyrrolnitrin from Burkholderia cepacia: Antibiotic activity against fungi and novel activities against streptomycetes. J. Appl. Microbiol. 1998, 85, 69-78. [CrossRef]

155. Velusamy, P.; Immanuel, J.E.; Gnanamanickam, S.S.; Thomashow, L. Biological control of rice bacterial blight by plant-associated bacteria producing 2,4-diacetylphloroglucinol. Can. J. Microbiol. 2006, 52, 56-65. [CrossRef]

156. Andreote, F.D.; Rossetto, P.B.; Mendes, R.; Avila, L.A.; Labate, C.A.; Pizzirani Kleiner, A.A.; Azevedo, J.L.; Araujo, W.L. Bacterial community in the rhizosphere and rhizoplane of wild type and transgenic eucalyptus. World J. Microbiol. Biotechnol. 2009, 25, 1065-1073. [CrossRef]

157. Zhang, L.; Tian, X.; Kuang, S.; Liu, G.; Zhang, C.; Sun, C. Antagonistic activity and mode of action of phenazine-1-carboxylic acid, produced by marine bacterium Pseudomonas aeruginosa PA31x, against Vibrio anguillarum in vitro and in a zebrafish in vivo model. Front Microbiol. 2017, 8, 289. [CrossRef] [PubMed]

158. Guo, B.; Wang, Y.; Sun, X.; Tang, K. Bioactive natural products from endophytes: A review. Appl. Biochem. Microbiol. 2008, 44, 136-142. [CrossRef]

159. Cho, K.M.; Hong, S.Y.; Lee, S.M.; Kim, Y.H.; Kahng, G.G.; Lim, Y.P.; Kim, H.; Yun, H.D. Endophytic bacterial communities in ginseng and their antifungal activity against pathogens. Microb. Ecol. 2007, 54, 341-351. [CrossRef] [PubMed]

160. Ezra, D.; Castillo, U.F.; Strobel, G.A.; Hess, W.M.; Porter, H.; Jensen, J.B.; Condron, M.A.M.; Teplow, D.B.; Sears, J.; Maranta, M.; et al. Coronamycins, peptide antibioticsproduced by a verticillate Streptomyces sp. (MSU-2110) endophytic on Monsterasp. Microbiology 2004, 150, 785-793. [CrossRef] [PubMed]

161. Asraful Islam, S.; Math, R.K.; Kim, J.; Yun, M.G.; Cho, J.J.; Kim, E.J.; Lee, Y.H.; Yun, H.D. Effect of Plant Age on Endophytic Bacterial Diversity of Balloon Flower (Platycodon grandiflorum) Root and Their Antimicrobial Activities. Curr. Microbiol. 2010, 61, 346-356. [CrossRef]

162. Farag, M.A.; Zhang, H.; Ryu, C.-M. Dynamic chemical communication between plants and bacteria through airborne signals: Induced resistance by bacterial volatiles. J. Chem. Ecol. 2013, 39, 1007-1018. [CrossRef]

163. De Vrieze, M.; Pandey, P.; Bucheli, T.D.; Varadarajan, A.R.; Ahrens, C.H.; Weisskopf, L.; Bailly, A. Volatile Organic Compounds from Native Potato-associated Pseudomonas as Potential Anti-oomycete Agents. Front. Microbiol. 2015, 6, 1295. [CrossRef]

164. Del Rosario Cappellari, L.; Chiappero, J.; Banchio, E. Invisible signals from the underground: A practical method to investigate the effect of microbial volatile organic compounds emitted by rhizobacteria on plant growth. Biochem. Mol. Biol. Educ. 2019, 47, 388-393. [CrossRef]

165. Sumayo, M.; Hahm, M.S.; Ghim, S.Y. Determinants of plant growth-promoting Ochrobactrum lupini KUDC1013 involved in induction of systemic resistance against Pectobacterium carotovorum subsp. Carotovorum in tobacco leaves. Plant Pathol. J. 2013, 29, 174-181. [CrossRef]

166. Tahir, H.A.S.; Qin, G.; Wu, H.; Niu, Y.; Rong, H.; Gao, X. Bacillus volatiles adversely affect the physiology and ultrastructure of Ralstonia solanacearum and induce systemic resistance in tobacco against Bacillus wilt. Sci. Rep. 2017, 7, 40481. [CrossRef] [PubMed]

167. Gutiérrez-Luna, F.M.; López-Bucio, J.; Altamirano-Hernández, J.; Valencia-Cantero, E.; De la Cruz, H.R.; Macías-Rodríguez, L. Plant growth-promoting rhizobacteria modulate root-system architecture in Arabidopsis thaliana through volatile organic compound emission. Symbiosis 2010, 51, 75-83. [CrossRef]

168. D'alessandro, M.; Erb, M.; Ton, J.; Brandenburg, A.; Karlen, D.; Zopfi, J.; Turlings, T.C. Volatiles produced by soil-borne endophytic bacteria increase plant pathogen resistance and affect tritrophic interactions. Plant Cell Environ. 2014, 37, 813-826. [CrossRef] [PubMed]

169. Rudrappa, T.; Biedrzycki, M.L.; Kunjeti, S.G.; Donofrio, N.M.; Czymmek, K.J.; Paré, P.W.; Bais, H.P. The rhizobacterial elicitor acetoin induces systemic resistance in Arabidopsis thaliana. Commun. Integr. Biol. 2010, 3, 130-138. [CrossRef]

170. Xie, S.; Liu, J.; Gu, S.; Chen, X.; Jiang, H.; Ding, T. Antifungal activity of volatile compounds produced by endophytic Bacillus subtilis DZSY21 against Curvularia lunata. Ann. Microbiol. 2020, 70, 1-10. [CrossRef]

171. Gao, Z.; Zhang, B.; Liu, H.; Han, J.; Zhang, Y. Identification of endophytic Bacillus velezensis ZSY-1 strain and antifungal activity of its volatile compounds against Alternaria solani and Botrytis cinerea. Biol. Control 2017, 105, 27-39. [CrossRef] 
172. Atmosukarto, I.; Castillo, U.; Hess, W.M.; Sears, J.; Strobel, G. Isolation and characterization of Muscodor albus I-41.3 s, a volatile antibiotic producing fungus. Plant Sci. 2005, 169, 854-861. [CrossRef]

173. Chan, K.-G.; Atkinson, S.; Mathee, K.; Sam, C.-K.; Chhabra, S.R.; Camara, M.; Koh, C.-L.; Williams, P. Characterization of $\mathrm{N}$-acylhomoserine lactone-degrading bacteria associated with the Zingiber officinale (ginger) rhizosphere: Co-existence of quorum quenching and quorum sensing in Acinetobacter and Burkholderia. BMC Microbiol. 2011, 11, 51. [CrossRef]

174. Zuniga, A.; Donoso, R.A.; Ruiz, D.; Ruz, G.A.; González, B. Quorum-sensing systems in the plant growth-promoting bacterium Paraburkholderia phytofirmans PsJN exhibit cross-regulation and are involved in biofilm formation. Mol. Plant-Microbe Interact. 2017, 30, 557-565. [CrossRef]

175. Steindler, L.; Venturi, V. Detection of quorum-sensing N-acyl homoserine lactone signal molecules by bacterial biosensors. FEMS Microbiol. Lett. 2007, 266, 1-9. [CrossRef]

176. Fuqua, W.C.; Winans, S.C. A LuxR-LuxI type regulatory system activates Agrobacterium Tiplasmid conjugal transfer in the presence of a plant tumor metabolite. J. Bacteriol. 1994, 176, 2796-2806. [CrossRef] [PubMed]

177. Elasri, M.; Delorme, S.; Lemanceau, P.; Stewart, G.; Laue, B.; Glickmann, E.; Oger, P.M.; Dessaux, Y. Acyl-homoserine lactone production is more common among plant-associated Pseudomonas spp. than among soilborne Pseudomonas spp. Appl. Environ. Microbiol. 2001, 67, 1198-1209. [CrossRef] [PubMed]

178. Marques, J.; Lamosa, P.; Russell, C. Quorum-sensing signal autoinducer-2 (AI-2) characterization of phospho-(S)-4, 5-dihydroxy2,3-pentanedione isomerization by LsrG protein. J. Biol. Chem. 2011, 286, 18331-18343. [CrossRef] [PubMed]

179. Liu, X.; Jia, J.; Popat, R.; Ortori, C.A.; Li, J.; Diggle, S.P.; Gao, K.; Camara, M. Characterisation of two quorum sensing systems in the endophytic Serratia plymuthica strain G3: Differential control of motility and biofilm formation according to life-style. BMC Microbiol. 2011, 11, 1-12. [CrossRef] [PubMed]

180. Vial, L.; Cuny, C.; Gluchoff-Fiasson, K.; Comte, G.; Oger, P.M.; Faure, D.; Dessaux, Y.; Bally, R.; Wisniewski-Dyé, F. N-acylhomoserine lactone -mediated quorum-sensing inAzospirillum: An exception rather than a rule. FEMS Microbiol. Ecol. 2006, 58, 155-168. [CrossRef]

181. Boyer, M.; Bally, R.; Perrotto, S.; Chaintreuil, C.; Wisniewski-Dyé, F. A quorum-quenching approach to identify quorum-sensingregulated functions in Azospirillum lipoferum. Res. Microbiol. 2008, 159, 699-708. [CrossRef]

182. Steidle, A.; Sigl, K.; Schuhegger, R.; Ihring, A.; Schmid, M.; Gantner, S.; Stoffels, M.; Riedel, K.; Givskov, M.; Hartmann, A.; et al. Visualization of $\mathrm{N}$-acylhomoserine lactone-mediated cell-cell communication between bacteria colonizing thetomato rhizosphere. Appl. Environ. Microbiol. 2001, 67, 5761-5770. [CrossRef]

183. Vandeputte, O.M.; Kiendrebeogo, M.; Rajaonson, S.; Diallo, B.; Mol, A.; El Jaziri, M.; Baucher, M. Identification of catechin as one of the flavonoids from Combretum albiflorum bark extract that reduces the production of quorum-sensing-controlled virulence factors in Pseudomonas aeruginosa PAO1. Appl. Environ. Microbiol. 2010, 76, 243-253. [CrossRef]

184. Pieterse, C.M.; Van der Does, D.; Zamioudis, C.; Leon-Reyes, A.; Van Wees, S.C. Hormonal modulation of plant immunity. Annu. Rev. Cell Dev. Biol. 2012, 28, 489-521. [CrossRef]

185. Diggle, S.P.; Cornelis, P.; Williams, P.; Camara, M. 4-Quinolone signalling in Pseudomonas aeruginosa: Old molecules, new perspectives. Int. J. Med. Microbiol. 2006, 296, 83-91. [CrossRef]

186. Suarez-Moreno, Z.R.; Devescovi, G.; Myers, M.; Hallack, L.; Mendonca-Previato, L.; Caballero-Mellado, J.; Venturi, V. Commonalities and differences in regulation of n-acyl homoserine lactone quorum sensing in the beneficial plant-associated burkholderia species cluster. Appl. Environ. Microbiol. 2010, 6, 4302-4317. [CrossRef]

187. Ryu, C.M.; Choi, H.K.; Lee, C.H.; Murphy, J.F.; Lee, J.K.; Kloepper, J.W. Modulation of Quorum Sensing in Acylhomoserine Lactone-Producing or -Degrading Tobacco Plants Leads to Alteration of Induced Systemic Resistance Elicited by the Rhizobacterium Serratia marcescens 90-166. Plant Pathol. J. 2013, 29, 182-192. [CrossRef] [PubMed]

188. Puopolo, G.; Cimmino, A.; Palmieri, M.C.; Giovannini, O.; Evidente, A.; Pertot, I. Lysobacter capsici AZ78 produces cyclo(L-Pro-LTyr), a 2,5-diketopiperazine with toxic activity against sporangia of Phytophthora infestans and Plasmopara viticola. J. Appl. Microbiol. 2014, 117, 1168-1180. [CrossRef] [PubMed]

189. Schuhegger, R.; Ihring, A.; Gantner, S.; Bahnweg, G.; Knappe, C.; Vogg, G.; Hutzler, P.; Schmid, M.; Breusegem, F.V.; Eberl, L.; et al. Induction of systemic resistance in tomato by $\mathrm{N}$-acyl-L-homoserine lactone-producing rhizosphere bacteria. Plant Cell Environ. 2006, 29, 909-918. [CrossRef] [PubMed]

190. Liu, X.; Jia, J.; Atkinson, S.; Camara, M.; Gao, K.; Li, H.; Cao, J. Biocontrol potential of an endophytic Serratia sp. G3 and its modeof action. World J. Microbiol. Biotechnol. 2010, 26, 1465-1471. [CrossRef]

191. Benhamou, N.; Kloepper, J.W.; Quadt-Hallmann, A.; Tuzun, S. Induction of defense-related ultrastructural modifications in pea root tissues inoculated with endophytic bacteria. Plant Physiol. 1996, 112, 919-929. [CrossRef]

192. Schenk, S.T.; Hernandez-Reyes, C.; Samans, B.; Stein, E.; Neumann, C.; Schikora, M.; Reichelt, M.; Mithofer, A.; Becker, A.; Kogel, K.-H.; et al. N-Acyl-Homoserine lactone primes plants for cell wall reinforcement and induces resistance to bacterial pathogens via the salicylic acid/oxylipin pathway. Plant Cell. 2014, 26, 2708-2723. [CrossRef]

193. Rosenblueth, M.; Martínez-Romero, E. Bacterial endophytes and their interactions with hosts. Mol. Plant Microbe Interact. 2006, 19, 827-837. [CrossRef]

194. Schroth, M.N.; Hancock, J.G. Disease-suppressive soil and root-colonizing bacteria. Science 1982, 216, 1376-1381. [CrossRef]

195. Iniguez, A.L.; Dong, Y.; Carter, H.D.; Ahmer, B.M.; Stone, J.M.; Triplett, E.W. Regulation of enteric endophytic bacterial colonization by plant defenses. Mol. Plant Microbe Interact. 2005, 18, 169-178. [CrossRef] 
196. Cavalcante, J.J.; Vargas, C.; Nogueira, E.M.; Vinagre, F.; Schwarcz, K.; Baldani, J.I.; Ferreira, P.C.; Hemerly, A.S. Members of the ethylene signalling pathway are regulated in sugarcane during the association with nitrogen-fixing endophytic bacteria. J. Exp. Bot. 2007, 58, 673-686. [CrossRef] [PubMed]

197. Frommel, M.I.; Nowak, J.; Lazarovits, G. Growth enhance-ment and developmental modifications of in vitro grown potato (Solanum tuberosum ssp. tuberosum) as affected by a nonfluorescent Pseudomonas sp. Plant Physiol. 1991, 96, 928-936. [CrossRef] [PubMed]

198. Sessitsch, A.; Coenye, T.; Sturz, A.V.; Vandamme, P.; Barka, E.A.; Salles, J.F.; Van Elsas, J.D.; Faure, D.; Reiter, B.; Glick, R.B.; et al. Burkholderia phytofirmans sp. nov., a novel plant-associated bacterium with plant-beneficial properties. Int. J. Syst. Evol. Microbiol. 2005, 55, 1187-1192. [CrossRef] [PubMed]

199. Compant, S.; Kaplan, H.; Sessitsch, A.; Nowak, J.; Barka, E.A.; Clement, C. Endophytic colonization of Vitis vinifera L. by Burkholderia phytofirmans strain PsJN: From the rhizosphere to inflorescence tissues. FEMS Microbiol. Ecol. 2008, 63, 84-93. [CrossRef] [PubMed]

200. Johnston-Monje, D.; Raizada, M.N. Conservation and diversity of seed associated endophytes in Zea across boundaries of evolution, ethnography and ecology. PLoS ONE 2011, 6, e20396. [CrossRef] [PubMed]

201. McCully, M.E. Niches for bacterial endophytes in crop plants: A plant biologist's view. Aust. J. Plant Physiol. 2001, 28, 983-990. [CrossRef]

202. Pankievicz, V.C.; Camilios-Neto, D.; Bonato, P.; Balsanelli, E.; Tadra-Sfeir, M.Z.; Faoro, H.; Chubatsu, L.S.; Donatti, L.; Wajnberg, G.; Passetti, F.; et al. RNA-seq transcriptional profiling of Herbaspirillum seropedicae colonizing wheat (Triticum aestivum) roots. Plant Mol. Biol. 2016, 90, 589-603. [CrossRef]

203. Alqueres, S.; Meneses, C.; Rouws, L.; Rothballer, M.; Baldani, I.; Schmid, M.; Hartmann, A. The bacterial superoxide dismutase and glutathione reductase are crucial for endophytic colonization of rice roots by Gluconacetobacter diazotrophicus PAL5. Mol. Plant Microbe Interact. 2013, 26, 937-945. [CrossRef]

204. Gehring, C.A.; Johnson, N.C. Beyond ICOM8: Perspectives on advances in mycorrhizal research from 2015 to 2017 . Mycorrhiza 2018, 28, 197-201. [CrossRef]

205. Martin, F.M.; Uroz, S.; Barker, D.G. Ancestral alliances: Plant mutualistic symbioses with fungi and bacteria. Science 2017, 356, eaad4501. [CrossRef]

206. Wezowicz, K.; Rozpadek, P.; Turna, K. Interactions of arbuscular mycorrhizal and endophytic fungiimprove seedling survival and growth in post-mining waste. Mycorrhiza 2017, 27, 499-511. [CrossRef] [PubMed]

207. Hashem, A.; Abd-Allah, E.F.; Alqarawi, A.A.; Al-Huqail, A.A.; Wirth Sand Egamberdieva, D. The interaction between arbuscular mycorrhizal fungi and endophytic bacteria enhances Plant growth of Acacia gerrardii under salt stress. Front. Microbiol. 2016, 7, 1089. [CrossRef] [PubMed]

208. Deveau, A.; Antony-Babu, S.; Le Tacon, F.; Robin, C.; Frey-Klett, P.; Uroz, S. Temporal changes of bacterial communities in the Tuber melanosporum ectomycorhizosphere during ascocarp development. Mycorrhiza 2016, 26, 389-399. [CrossRef] [PubMed]

209. Marupakula, S.; Mahmood, S.; Finlay, R.D. Analysis of single root tip microbiomes suggests that distinctive bacterial communities are selected by Pinus sylvestris roots colonized by different ectomycorrhizal fungi. Environ. Microbiol. 2016, 18, 1470-1483.

210. Nguyen, N.H.; Bruns, T.D. The microbiome of Pinus muricata ectomycorrhizae: Community assemblages, fungal species effects, and Burkholderia as important bacteria in multi-partnered symbioses. Microb. Ecol. 2015, 69, 914-921. [CrossRef]

211. Akyol, T.Y.; Niwa, R.; Hirakawa, H.; Maruyama, H.; Sato, T.; Suzuki, T.; Fukunaga, A.; Sato, T.; Yoshida, S.; Tawaraya, K.; et al. Impact of introduction of arbuscular mycorrhizal fungi on the root microbial community in Agricultural Fields. Microbes Environ. 2019, 34, 23-32. [CrossRef]

212. Vannini, C.; Carpentieri, A.; Salvioli, A.; Novero, M.; Marsoni, M.; Testa, L.; De Pinto, M.C.; Amoresano, A.; Ortolani, F.; Bracale, M.; et al. An interdomain network: The endobacterium of a mycorrhizal fungus promotes antioxidative responses in both fungal and plant hosts. N. Phytol. 2016, 211, 265-275. [CrossRef]

213. Lavania, M.; Chauhan, P.S.; Chauhan, S.V.; Singh, H.B.; Nautiyal, C.S. Induction of plant defense enzymes and phenolics by treatment with plant growth-promoting rhizobacteria Serratia marcescens NBRI1213. Curr. Microbiol. 2006, 52, 363-368. [CrossRef]

214. Dardanelli, M.S.; Manyani, H.; Gonzalez-Barroso, S.; Rodriguez-Carvajal, M.A.; Gil-Serrano, A.M.; Espuny, M.R.; LópezBaena, F.J.; Bellogín, R.A.; Megías, M.; Ollero, F.J. Effect of the presence of the plant growth promoting rhizobacterium (PGPR) Chryseobacterium balustinum Aur9 and salt stress in the pattern of flavonoids exuded by soybean roots. Plant Soil 2010, 328, 483-493. [CrossRef]

215. Burdman, S.; Volpin, H.; Kigel, J.; Kapulnik, Y.; Okon, Y. Promotion of nod gene inducers and nodulation in common bean (Phaseolus vulgaris) roots inoculated with Azospirillum brasilense Cd. Appl. Environ. Microbiol. 1996, 62, 3030-3033. [CrossRef]

216. Curzi, M.J.; Ribaudo, C.M.; Trinchero, G.D.; Cura, J.A.; Pagano, E.A. Changes in the content of organic and amino acids and ethylene production of rice plants in response to the inoculation with Herbaspirillum seropedicae. J. Plant Interact. 2008, 3, 163-173. [CrossRef]

217. Bharti, N.; Yadav, D.; Barnawal, D.; Maji, D.; Kalra, A. Exiguobacterium oxidotolerans, a halotolerant plant growth promoting rhizobacteria, improves yield and content of secondary metabolites in Bacopa monnieri (L.) Pennell under primary and secondary salt stress. World J. Microbiol. Biotechnol. 2013, 29, 379-387. [CrossRef] [PubMed] 
218. Chamam, A.; Sanguin, H.; Bellvert, F.; Meiffren, G.; Comte, G.; Wisniewski-Dyé, F.; Bertrand, C.; Pringent-Combaret, C. Plant secondary metabolite profiling evidences strain-dependent effect in the Azospirillum-Oryza sativa association. Phytochemistry 2013, 87, 65-77. [CrossRef] [PubMed]

219. Rozpadek, P.K.; Wężowicz, M.; Nosek, R.; Ważny, K.; Tokarz, M.; Lembicz, M.; Miszalski, Z.; Turnau, K. The fungal endophyte Epichloë typhina improves photosynthesis efficiency of its host orchard grass (Dactylis glomerata). Planta 2015, 242, 1025-1035 [CrossRef]

220. Schliemann, W.; Ammer, C.; Strack, D. Metabolite profiling of mycorrhizal roots of Medicago truncatula. Phytochemistry 2008, 69, 112-146. [CrossRef]

221. Rasmussen, S.; Parsons, A.J.; Fraser, K.; Xue, H.; Newman, J.A. Metabolic profiles of Lolium perenne are differentially affected by nitrogen supply, carbohydrate content, and fungal endophyte infection. Plant Physiol. 2008, 146, 1440-1453. [CrossRef]

222. Bacilio-Jiménez, M.; Aguilar-Flores, S.; Ventura-Zapata, E.; Pérez-Campos, E.; Bouquelet, S.; Zenteno, E. Chemical characterization of root exudates from rice (Oryza sativa) and their effects on the chemotactic response of endophytic bacteria. Plant Soil 2003, 249, 271-277. [CrossRef]

223. Jha, Y.; Subramanian, R.; Patel, S. Combination of endophytic and rhizospheric plant growth promoting rhizobacteria in Oryza sativa shows higher accumulation of osmoprotectant against saline stress. Acta Physiol. Plant. 2011, 33, 797-802. [CrossRef]

224. Hiruma, K.; Gerlach, N.; Sacristán, S.; Nakano, R.T.; Hacquard, S.; Kracher, B.; Neumann, U.; Ramirez, D.; Bucher, M.; O’Connell, R.J.; et al. Root Endophyte Colletotrichum tofieldiae confers plant fitness benefits that are phosphate status dependent. Cell 2016, 165, 464-474. [CrossRef]

225. Amrani, A.E.; Dumas, A.; Wick, L.Y.; Yergeau, E.; Berthomee, R. Omics insights into PAH degradation toward improved Green remediation biotechnologies. Environ. Sci. Technol. 2015, 49, 11281-11291. [CrossRef]

226. Tian, B.-Y.; Cao, Y.; Zhang, K.-Q. Metagenomic insights into communities, functions of endophytes, and their associates with infection by root-knot nematode, Meloidogyne incognita, in tomato roots. Sci. Rep. 2015, 5, 1-15. [CrossRef] [PubMed]

227. Maropola, M.K.A.; Ramond, J.-B.; Trindade, M. Impact of metagenomic DNA extraction procedures on the identifiable endophytic bacterial diversity in Sorghum bicolor (L. Moench). J. Microbiol. Methods 2015, 112, 104-117. [CrossRef] [PubMed]

228. Ardanov, P.; Sessitsch, A.; Haggman, H.; Kozyrovska, N.; Pirttila, A.M. Methylobacterium -induced endophyte community changes correspond with protection of plants against pathogen attack. PLoS ONE 2012, 7, e46802. [CrossRef] [PubMed]

229. Sessitsch, A.; Hardoim, P.; Doring, J.; Weilharter, A.; Krause, A.; Woyke, T.; Mitter, B.; Hauberg-Lotte, L.; Friedrich, F.; Rahalkar, M.; et al. Functional Characteristics of an Endophyte Community Colonizing Rice Roots as Revealed by Metagenomic Analysis. MPMI 2012, 25, 28-36. [CrossRef] [PubMed]

230. Dong, C.-J.; Wang, L.-L.; Li, Q.; Shang, Q.-M. Bacterial communities in the rhizosphere, phyllosphere and endosphere of tomato plants. PLoS ONE 2019, 14, e022384. [CrossRef]

231. Long, H.H.; Sonntag, D.G.; Schmidt, D.D.; Baldwin, I.T. The structure of the culturable root bacterial endophyte community of Nicotiana attenuata is organized by soil composition and host plant ethylene production and perception. N. Phytol. 2010, 185, 554-567. [CrossRef]

232. Puri, R.R.; Adachi, F.; Omichi, M.; Saeki, Y.; Yamamoto, A.; Hayashi, S.; Ali, M.A.; Itoh, K. Metagenomic study of endophytic bacterial community of sweet potato (Ipomoea batatas) cultivated in different soil and climatic conditions. World J. Microbiol. Biotechnol. 2019, 35, 176. [CrossRef]

233. Carrión, V.J.; Perez-Jaramillo, J.; Cordovez, V.; Tracanna, V.; De Hollander, M.; Ruiz-Buck, D.; Mendes, L.W.; van Ijcken, W.F.J.; Gomez-Exposito, R.; Elsayed, S.S.; et al. Pathogen-induced activation of disease-suppressive functions in the endophytic root microbiome. Science 2019, 366, 606-612. [CrossRef]

234. Pinto-Carbó, M.; Sieber, S.; Dessein, S.; Wicker, T.; Verstraete, B.; Gademann, K.; Eberl, L.; Carlier, A. Evidence of horizontal gene transfer between obligate leaf nodule symbionts. ISME J. 2016, 10, 2092-2105. [CrossRef]

235. Cheng, Z.; Mcconkey, B.J.; Glick, B.R. Proteomic studies of plant-bacterial interactions. Soil Biol. Biochem. 2010, 42, 1673-1684. [CrossRef]

236. Maron, P.; Ranjard, L.; Mougel, C.; Lemanceau, P. Metaproteomics: A new approach for studying functional microbial ecology. Microb. Ecol. 2007, 53, 486-493. [CrossRef] [PubMed]

237. Witzel, K.; Üstün, S.; Schreiner, M.; Grosch, R.; Börnke, F.; Ruppel, S. A proteomic approach suggests unbalanced proteasome functioning induced by the growth-promoting bacterium Kosakonia radicincitans in Arabidopsis. Front. Plant Sci. 2017,8 , 661. [CrossRef] [PubMed]

238. Chi, F.; Yang, P.; Han, F.; Jing, Y.; Shen, S. Proteomic analysis of rice seedlings infected by Sinorhizobium meliloti 1021. Proteomics 2010, 10, 1861-1874. [PubMed]

239. Lery, L.M.S.; Hemerly, A.S.; Nogueira, E.M.; Von, K.; Ruger, W.M.A.; Bisch, P.M. Quantitative proteomic analysis of the interaction between the endophytic plant-growth-promoting bacterium Gluconacetobacter diazotrophicus and sugarcane. Mol. Plant-Microbe Interact. 2011, 24, 562-576. [CrossRef]

240. Miche, L.; Battistoni, F.; Gemmer, S.; Belghazi, M.; Reinhold-Hurek, B. Upregulation of jasmonate-inducible defense proteins and differential colonization of roots of Oryza sativa cultivars with the endophyte Azoarcus sp. Mol. Plant-Microbe Interact. 2006, 19, 502-511. [CrossRef] [PubMed] 
241. Srivastava, S.; Chaudhry, V.; Mishra, A.; Chauhan, P.S.; Rehman, A.; Yadav, A.; Tuteja, N.; Nautiyal, C.S. Gene expression profiling through microarray analysis in Arabidopsis thaliana colonized by Pseudomonas putida MTCC5279, a plant growth promoting rhizobacterium. Plant Signal. Behav. 2012, 7, 235-245. [CrossRef]

242. Vargas, L.; Gurjao de Carvalho, T.L.; Gomes Ferreira, P.C.; Baldani, V.L.; Baldani, J.I.; Hemerly, A.S. Early responses of rice (Oryza sativa L.) seedlings to inoculation with beneficial diazotrophic bacteria are dependent on plant and bacterial genotypes. Plant Soil 2012, 356, 127-137. [CrossRef]

243. Brusamarello-Santos, L.C.C.; Pacheco, F.; Aljanabi, S.M.M.; Monteiro, R.A.; Cruz, L.M.; Baura, V.A.; Pedrosa, F.O.; Souza, E.M.; Wassem, R. Differential gene expression of rice roots inoculated with the diazotroph Herbaspirillum seropedicae. Plant Soil 2012, 356, 113-125. [CrossRef]

244. Verhagen, B.W.; Glazebrook, J.; Zhu, T.; Chang, H.S.; Van Loon, L.C.; Pieterse, C.M. The transcriptome of rhizobacteria-induced systemic resistance in Arabidopsis. Mol. Plant-Microbe Interact. 2004, 17, 895-908. [CrossRef]

245. Van de Mortel, J.E.; De Vos, R.C.; Dekkers, E.; Pineda, A.; Guillod, L.; Bouwmeester, K.; van Loon, J.J.A.; Dicke, M.; Raaijmakers, J.M. Metabolic and transcriptomic changes induced in Arabidopsis by the rhizobacterium Pseudomonas fluorescens SS101. Plant Physiol. 2012, 160, 2173-2188. [CrossRef]

246. Maketon, C.; Fortuna, A.M.; Okubara, P.A. Cultivar-dependent transcript accumulation in wheat roots colonized by Pseudomonas fluorescens Q8r1-96 wild type and mutant strains. Biol. Control 2012, 60, 216-224. [CrossRef]

247. Yi, Y.; De Jong, A.; Frenzel, E.; Kuipers, O.P. Comparative transcriptomics of Bacillus mycoides strains in response to potato-root exudates reveals different genetic adaptation of endophytic and soil isolates. Front. Microbiol. 2017, 8, 1487. [CrossRef] [PubMed] 